\title{
Sensitivity studies on the impacts of Tibetan Plateau snowpack pollution on the Asian hydrological cycle and monsoon climate
}

\author{
Y. Qian ${ }^{1}$, M. G. Flanner ${ }^{2}$, L. R. Leung ${ }^{1}$, and W. Wang ${ }^{3}$ \\ ${ }^{1}$ Pacific Northwest National Laboratory, Richland, WA, USA \\ ${ }^{2}$ University of Michigan, Ann Arbor, MI, USA \\ ${ }^{3}$ NOAA National Centers for Environmental Prediction, Camp Springs, MD, USA
}

Received: 27 August 2010 - Published in Atmos. Chem. Phys. Discuss.: 5 October 2010

Revised: 21 January 2011 - Accepted: 16 February 2011 - Published: 2 March 2011

\begin{abstract}
The Tibetan Plateau (TP) has long been identified to be critical in regulating the Asian monsoon climate and hydrological cycle. In this modeling study a series of numerical experiments with a global climate model are designed to simulate radiative effect of black carbon (BC) and dust in snow, and to assess the relative impacts of anthropogenic $\mathrm{CO}_{2}$ and carbonaceous particles in the atmosphere and snow on the snowpack over the TP and subsequent impacts on the Asian monsoon climate and hydrological cycle. Simulations results show a large BC content in snow over the TP, especially the southern slope. Because of the high aerosol content in snow and large incident solar radiation in the low latitude and high elevation, the TP exhibits the largest surface radiative flux changes induced by aerosols (e.g. BC, Dust) in snow compared to any other snow-covered regions in the world.

Simulation results show that the aerosol-induced snow albedo perturbations generate surface radiative flux changes of $5-25 \mathrm{~W} \mathrm{~m}^{-2}$ during spring, with a maximum in April or May. BC-in-snow increases the surface air temperature by around $1.0^{\circ} \mathrm{C}$ averaged over the TP and reduces spring snowpack over the TP more than pre-industrial to present $\mathrm{CO}_{2}$ increase and carbonaceous particles in the atmosphere. As a result, runoff increases during late winter and early spring but decreases during late spring and early summer (i.e. a trend toward earlier melt dates). The snowmelt efficacy, defined as the snowpack reduction per unit degree of warming induced by the forcing agent, is 1-4 times larger for BC-in-snow than $\mathrm{CO}_{2}$ increase during April-July, indicating that $\mathrm{BC}$-in-snow more efficiently accelerates snowmelt because the increased net solar radiation induced by reduced albedo melts the snow more efficiently than snow melt due to warming in the air.
\end{abstract}

The TP also influences the South (SAM) and East (EAM) Asian monsoon through its dynamical and thermal forcing. Simulation results show that during boreal spring aerosols are transported by southwesterly, causing some particles to reach higher altitude and deposit to the snowpack over the TP. While BC and Organic Matter (OM) in the atmosphere directly absorb sunlight and warm the air, the darkened snow surface polluted by $\mathrm{BC}$ absorbs more solar radiation and increases the skin temperature, which warms the air above through sensible heat flux. Both effects enhance the upward motion of air and spur deep convection along the TP during the pre-monsoon season, resulting in earlier onset of the SAM and increase of moisture, cloudiness and convective precipitation over northern India. BC-in-snow has a more significant impact on the EAM in July than $\mathrm{CO}_{2}$ increase and carbonaceous particles in the atmosphere. Contributed by the significant increase of both sensible heat flux associated with the warm skin temperature and latent heat flux associated with increased soil moisture with long memory, the role of the TP as a heat pump is elevated from spring through summer as the land-sea thermal contrast increases to strengthen the EAM. As a result, both southern China and northern China become wetter, but central China (i.e. Yangtze River Basin) becomes drier - a near-zonal anomaly pattern that is consistent with the dominant mode of precipitation variability in East Asia.

The snow impurity effects reported in this study likely represent some upper limits as snowpack is remarkably overestimated over the TP due to excessive precipitation. Improving the simulation of precipitation and snowpack will be important for improved estimates of the effects of snowpack pollution in future work.

Correspondence to: Y. Qian

(yun.qian@pnl.gov)

Published by Copernicus Publications on behalf of the European Geosciences Union. 


\section{Introduction}

Snow albedo is important in determining the surface energy transfer within the cryosphere. One factor that affects snow albedo is the presence of absorbing particles (e.g. soot, dust) (Warren and Wiscombe, 1980, 1985; Painter et al., 2007). The visible snowpack albedo can be reduced from 0.95 for pure snow to 0.1 for dirty snow with $100 \mathrm{ppm}$ by weight (ppmw) of soot (Warren and Wiscombe, 1980). Although estimates of present-day global-mean radiative forcing (RF) from soot in snow are only $\sim 0.04-0.20 \mathrm{~W} \mathrm{~m}^{-2}$, the local RF could be much higher. Climate models suggest this mechanism has greater efficacy than any other anthropogenic agent (Hansen and Nazarenko, 2004; Jacobson, 2004; Hansen et al., 2005; Flanner et al., 2007; Qian et al., 2009a), owing largely to its effectiveness in removing snow cover. The 2007 IPCC report listed the radiative forcing induced by "soot on snow" as one of the important anthropogenic forcings affecting climate change. It is important to understand the control of snow cover evolution because most of the interannual variability in mid- and high-latitude planetary albedo is caused by changes in snow and sea-ice cover (Qu and Hall, 2006). Modeling studies have shown that the long-term average of snow accumulation or melt patterns may significantly alter global and regional climate and have a strong impact upon the general circulation and hydrological cycle (e.g., Barnett et al., 1988; Qian et al., 2009a).

The Tibetan Plateau (TP) is the highest and largest plateau in the world. It covers an area of 3.6 million $\mathrm{km}^{2}$ at $2000 \mathrm{~m}$ above the mean sea level (MSL) (see Fig. 1). Glaciers on the TP hold the largest ice mass outside the Polar region and the snowpack can persist year round at higher altitude regions over the TP (Xu et al., 2009; Pu and Xu, 2009). The TP has long been identified to be critical in regulating the Asian hydrological cycle and monsoon climate (e.g. Yanai et al., 1992; Wu and Zhang, 1998; Xu and Chan, 2001). First, the glaciers over the TP act as a water storage tower for South Asia, Southeast Asia and East Asia. Precipitation and released melt water from the TP provide fresh water to billions of people through the major rivers that originate from the TP. For example, the glacial and snow melt provides up to twothirds of the summer flow in the Ganges and half or more of the flow in other major rivers (Qin et al., 2006). The longterm trend and/or seasonal shift of water resource provided by the TP may significantly affect agriculture, hydropower and even national security for the developing countries in the region.

Second, thermal heating of the TP has profound dynamical influences on the atmospheric circulation in the Northern Hemisphere (Manabe and Terpstra, 1974; Yeh et al., 1979). Anomalous snow cover can influence the energy and water exchange between the land surfaces and the lower troposphere by modulating radiation, water and heat flux (Cohen and Rind, 1991). Lau and Kim (2006) and Lau et al. (2006) proposed a so-called Elevated Heat Pump (EHP) effect,

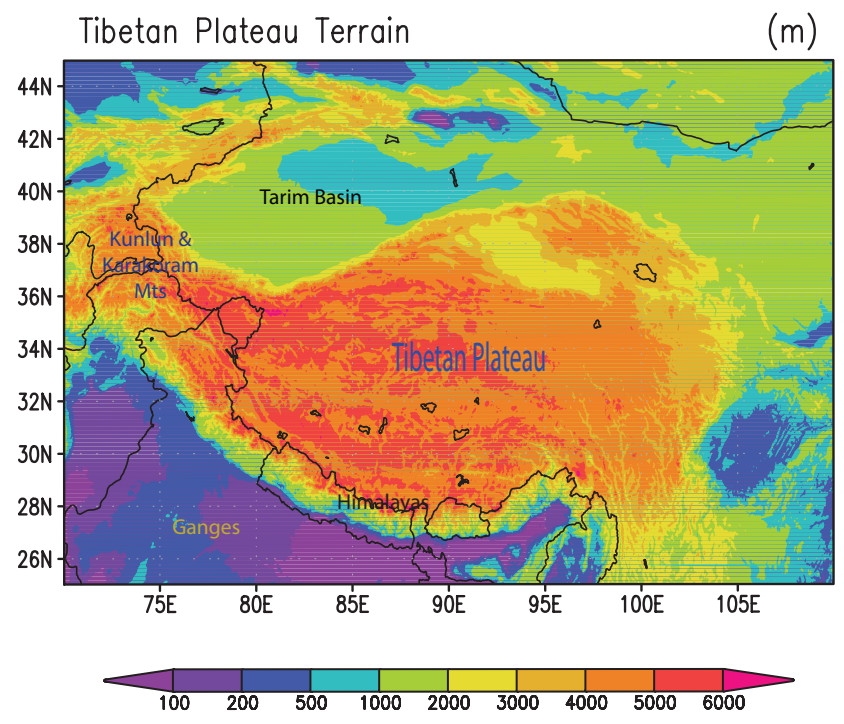

Fig. 1. Terrain of Tibetan Plateau (Unit: m).

whereby heating of the atmosphere by elevated absorbing aerosols strengthens local atmospheric circulation, leading to a northward shift of the monsoon rain belt, with increased rainfall in northern India and the foothills of the Himalayas in the late boreal spring and early summer season. Although Nigam and Bollasina (2010) showed that there is little observational evidence that supports the EHP because the observed aerosol and precipitation anomalies are in fact not collocated, their analysis of hydroclimate lagged regressions on aerosols suggests that precipitation anomalies in Northern India can be interpreted as impacts of aerosols, rather than an aerosol-precipitation relationship due to aerosol removal by precipitation. Lau and Kim (2011) argued that validation of the EHP has to be based on the forcing and response of the entire monsoon system from pre-onset to termination, and not based on local correlation of aerosol and rainfall at one time. Meanwhile, many studies based on modeling and observational data analysis have found a remarkable relationship between the winter or spring snow over the TP and rainfall over the mid- and lower-reaches of the Yangtze River Basin (YRB) in eastern China and South China in the subsequent summer (e.g. Wu and Qian, 2003; Qian et al., 2003; Zhang et al., 2004), primarily through two important effects of snow cover - influence on surface albedo and soil moisture (Barnett et al., 1989; Yasunari et al., 1991).

Observational evidence indicates that the surface temperatures on the TP have increased by about $1.8^{\circ} \mathrm{C}$ over the past 50 years (Wang et al., 2008). IPCC 2007 reported that under the $\mathrm{A} 1 \mathrm{~B}$ emissions scenario, a $4{ }^{\circ} \mathrm{C}$ warming will likely occur over the TP during the next $100 \mathrm{yr}$ (Meehl et al., 2007). Both observed and projected warming over the TP is much larger than the global average. Consequently, the glaciers on the TP have been retreating extensively in past decades (Qin et al., 2006). In the short term, this will cause lakes to expand 
and bring floods and mudflows. In the long run, the glaciers are vital lifelines for Asian rivers such as the Indus and the Ganges. Once they vanish, water supplies in those regions will be in peril.

Accelerated melt of global snowpack and glaciers is driven by warming due to increasing greenhouse gases (GHGs) (Barnett et al., 2005), but the larger rate of warming and rapidity of glacier retreat suggest that additional mechanisms may be involved (Xu et al., 2009). The TP is located close to regions in South and East Asia that have been and are predicted to continue to be the largest sources of BC in the world (Bond et al., 2006; Menon et al., 2010). For example, the Indian sub-continent, especially the Indo-Gangetic Plain, is one of the largest BC emission sources in the world (Ramanathan et al., 2007). Although the Himalayas may inhibit transport from the Gangetic Plain to the TP, some BC is transported and deposited to snow in the Himalayas and TP. Himalayan ice core records indicate a significant increase in deposition of both BC and OC over the northern slope of the TP, especially since 1990 (Ming et al., 2008; Xu et al., 2009).

In contrast to the more straightforward radiative effects of GHGs in the atmosphere, atmospheric particles influence the snowpack energy budget in more complicated ways via several mechanisms (Flanner et al., 2009). First, through absorption and scattering, aerosols reduce downwelling insolation at the surface (dimming) (e.g., Ogren and Charlson, 1983; Qian et al., 2006), thus decreasing absorbed solar energy by snowpack. Second, absorbing particles (e.g. soot) may warm the troposphere via solar heating. Recent observational studies attributed the accelerated warming of the troposphere over the TP to atmospheric heating by aerosols (Gautam et al., 2009a, b; Prasad et al., 2009). Ramanathan et al. (2007) suggest that brown clouds contribute as much surface air warming over the Himalayas as anthropogenic greenhouse gases. This warming may transfer thermal energy into snow and drive earlier melt, but may also stabilize the atmosphere and reduce surface-air energy exchange. Based on GCM experiment, Lau et al. (2010) find that atmospheric heating by black carbon and dust can induce a reduction of the Himalayan and Tibetan snowpack cover by $6-10 \%$, without greenhouse warming. Third, deposited particles (e.g. soot) reduce snow reflectance (surface darkening), counteracting the dimming effect. BC measurements in Mt. Everest ice core show mixing ratios that produced a summer darkening effect of $4.5 \mathrm{~W} \mathrm{~m}^{2}$ in 2001 (Ming et al., 2008). The surface darkening caused by dirty snow may be magnified with the snow aging process, which can be accelerated under warmer climate.

In this study, we simulate the deposition and concentration of black carbon (BC) and dust over the TP, and calculate their radiative effect (i.e., impact on surface radiative flux changes, SRFC). We strive to understand the relative and combined impacts of anthropogenic $\mathrm{CO}_{2}$ and carbonaceous particles in the atmosphere and snow on the snowpack over the TP, as well as their subsequent impacts on the Asian monsoon climate and hydrological cycle, based on a series of global climate simulations with various combinations of active carbonaceous aerosols and $\mathrm{CO}_{2}$. Carbonaceous aerosol effects can be active or inactive in the atmosphere and in snow in the simulations, respectively, and the effect of different $\mathrm{CO}_{2}$ concentration is also simulated and compared with that for the aerosols. Our analysis focuses on the change of springtime snowpack over the TP and their subsequent impacts on the SRFC and hydrological cycle (Sect. 3) and summer monsoon climate over the India and East Asia (Sect. 4).

\section{Model evaluation and experiments design}

\subsection{Model and experiments}

Equilibrium global climate model (GCM) experiments were conducted with the National Center for Atmospheric Research (NCAR) Community Atmosphere Model version 3.1 (CAM) (e.g., Collins et al., 2006) with resolution $\sim 2.8^{\circ} \times 2.8^{\circ}$ near the equator. These simulations applied a slab ocean model to allow for fast equilibration, and were forced with constant greenhouse gas levels and monthlyvarying, annually-repeating concentrations of mineral dust, sulfate, and sea-salt from an assimilation (Collins et al., 2001). BC and organic matter (OM) were treated prognostically (Rasch et al., 2000, 2001), with annually-repeating emissions (i.e., varying by month but identical each year) from a global $1^{\circ} \times 1^{\circ}$ inventory (Bond et al., 2004), representing the values at 1996 . Emissions of organic carbon from this inventory were multiplied by 1.4 to represent organic matter. This OM:OC ratio is appropriate for fossil OC emissions (Russell, 2003). Biofuel and biomass burning emissions can contain higher ratios. The prescribed biomass burning OM emissions (and hence OM:OC ratios) vary with vegetation type (van der Werf et al., 2006). Hydrophobic species were transformed to hydrophilic with an e-folding time of 1.2 days. BC optical properties were modified to conform to Bond and Bergstrom (2006), and include an absorption enhancement factor of 1.5 for coated hydrophilic particles (Bond et al., 2006). Optical properties for OM (Hess et al., 1998) include dependence on local relative humidity. The OM effect in snow is very small based on the sensitivity experiments we did, so we simply turned it off in this study. $\mathrm{BC}$ and mineral dust in snow were treated with the Snow, Ice, and Aerosol Radiative (SNICAR) component of CAM, described by Flanner et al. $(2007,2009)$. We also apply the representation of snow cover fraction (Niu and Yang, 2007), dependent on snow depth and density, that is included CLM 4.0 .

The $\mathrm{BC}$ content in snow follows from the simulated lifecycle of $\mathrm{BC}$, starting with emissions. Hence, our definition of BC is identical to that used in Bond et al. (2004) in developing the emission inventories, namely: "the mass of combustion-generated, sp2-bonded carbon that absorbs 
Table 1. Model experiments.

\begin{tabular}{lccccc}
\hline $\begin{array}{l}\text { Experiment } \\
\text { Case }\end{array}$ & $\begin{array}{c}\mathrm{CO}_{2} \\
(\mathrm{ppm})\end{array}$ & $\begin{array}{c}\mathrm{FF}+\mathrm{BF} \mathrm{BC}+\mathrm{OM} \\
\text { active in atmos.? }\end{array}$ & $\begin{array}{c}\mathrm{FF}+\mathrm{BF} \mathrm{BC} \\
\text { active in snow? }\end{array}$ & $\begin{array}{c}\mathrm{BB} \mathrm{BC+OM} \text { and dust } \\
\text { betive in atmos.? }\end{array}$ & $\begin{array}{c}\mathrm{BB} \mathrm{BC} \mathrm{and} \mathrm{dust}^{\mathrm{b}} \\
\text { active in snow? }\end{array}$ \\
\hline pi1 $^{\mathrm{c}}$ & 289 & no & no & no & no \\
pi2 & 380 & no & no & no & no \\
pi3 & 289 & yes & no & no & no \\
pi4 & 289 & no & yes & no & no \\
pi6 & 380 & yes & yes & yes & yes \\
pd1 & d & yes & yes & & \\
\hline
\end{tabular}

${ }^{a}$ Fossil fuel and biofuel black carbon and organic matter. ${ }^{b}$ Biomass burning black carbon and mineral dust. ${ }^{c}$ pi is initialized with pre-industrial climate. ${ }^{d}$ pd applies present-day boundary conditions and $\mathrm{CO}_{2}$ level.

the same amount of light as the emitted particles". Thus, the simulated BC is indeed refractory-like, but is meant to account for an identical amount of light absorption as the emitted refractory BC and colored organics. Dust was not the focus of this study, but we included dust in experiment pd1 to achieve a more realistic simulation. Prognostic dust emissions are based on the Dust Entrainment and Deposition Model (Zender et al., 2003), and advected in 4 bulk size bins. Dust emissions are prognostic, and depend on local soil moisture, surface wind speed, soil erodibility, and vegetation. Hence model dust emissions vary seasonally and inter-annually. Dust processes in this version of CAM are summarized in Mahowald et al. (2006). The visible singlescattering albedo values assumed for the four size bins of dust in snow range from 0.88 (largest size) to 0.99 (smallest size), as mentioned in Flanner et al. (2009). In the experiment pd1 the dust is included together with Biomass Burning (BB) $\mathrm{BC}$ and $\mathrm{OM}$, so dust effect cannot be isolated in the current experiment design.

Configurations of model experiments are described in Table 1. These experiments were designed to assess the relative climate impacts of anthropogenic $\mathrm{CO}_{2}$ and carbonaceous particles in the atmosphere and snow, and are a subset of those experiments described by Flanner et al. (2009). Experiments tagged "pi" were initialized with pre-industrial climate, whereas experiment pd1 applied present-day boundary conditions. Experiment pi1 is a control simulation, with pre-industrial $\mathrm{CO}_{2}$ levels and $\mathrm{BC}+\mathrm{OM}$ inactive in the atmosphere and snowpack. Experiment pi2 applies modern $\mathrm{CO}_{2}$ levels $(380 \mathrm{ppm})$, but maintains inactive carbonaceous particles. Experiment pi3 maintains pre-industrial $\mathrm{CO}_{2}$ levels, but includes active fossil and biofuel sources of $\mathrm{BC}+\mathrm{OM}$ in the atmosphere. Experiment pi4 also maintains pre-industrial $\mathrm{CO}_{2}$ levels, but includes active fossil and biofuel sources of $\mathrm{BC}$ in the snow. Experiment pi6 introduces all three forcing mechanisms (modern $\mathrm{CO}_{2}$, active $\mathrm{BC}+\mathrm{OM}$ in atmosphere and $\mathrm{BC}$ in snow). Finally, experiment pd 1 applies full modern conditions, including all sources of carbonaceous particles (fossil, biofuel, and biomass burning) and mineral dust active in both the atmosphere and snowpack. Biomass burning BC + OM emissions applied in pd1 were 1997-2006 mean emissions from the Global Fire Emissions Database (van der Werf et al., 2006), version 2 (GFEDv2).

In all equilibrium experiments, results were averaged over the last $15 \mathrm{yr}$ of the 50 -yr simulations, during which the TOA net energy flux showed no significant trend. So we are giving the system $35 \mathrm{yr}$ to equilibrate. Statistical difference between the simulations was determined with two-sided pooled t-tests, using realizations from each of the 15 analysis years. Since the climate had equilibrated by the beginning of the 15 -yr period, each year is treated as an independent sample of the equilibrium state. Thus, statistical significance is defined relative to the inherent inter-annual variability in the model.

\subsection{Evaluation}

To simulate the impacts of aerosol-induced snow albedo change, it is important to assess the basic features of the simulated climatic variables, especially the snowpack and the aerosol content in snow. A more detailed evaluation for CAM3 performance in simulating the climate variables can be found in Collins et al. (2006). Here we just give a brief comparison of the measured and CAM-simulated snow cover fraction and $\mathrm{BC}$ content in snow over the TP. Controlled by precipitation and complex terrain over the TP, snow cover fraction (SCF), as retrieved from the Moderate Resolution Imaging Spectrometer (MODIS) and shown in Fig. 2, exhibits an extremely inhomogeneous spatial distribution, with higher SCF in the mountain ranges ( $\mathrm{Pu}$ and $\mathrm{Xu}, 2009)$. The most persistent snow-covered areas (i.e. $\mathrm{SCF}>50 \%$ ) are located over the Himalayas, Karakoram, Kunlun ranges and the western part of the Yarlung Zangbo Valley, especially the conjunction areas between the Karakoram and Kunlun glacier mountains with more than $70 \%$ of snow/ice covered days annually. In the southeast TP, the SCF is also higher because of heavy precipitation resulting from the abundant moisture of the Yarlung Zangbo Valley. Due to rain shadow 

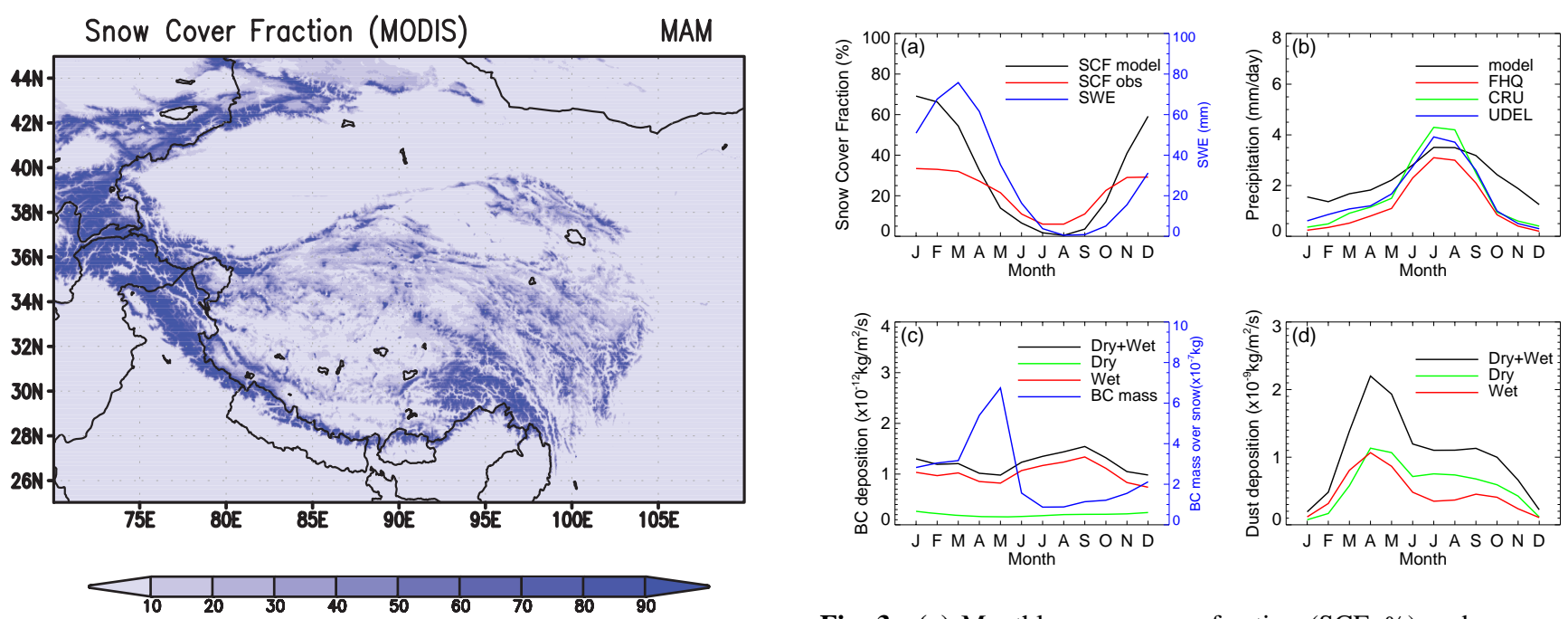

Fig. 3. (a) Monthly snow cover fraction (SCF, \%) and sow water equivalence (SWE, mm) from model, and SCF from MODIS; (b) monthly precipitation ( $\mathrm{mm}$ per day) from model and three different observational datasets (see Qian and Leung, 2007); (c) dry, wet and total deposition for BC $\left(10^{-12} \mathrm{~kg} \mathrm{~m}^{-2} \mathrm{~s}^{-1}\right)$ and the mass of $\mathrm{BC}$ in top snow layer averaged over the areas when snow presents $\left(10^{-7} \mathrm{~kg}\right)$; (d) dry, wet and total deposition for dust $\left(10^{-9} \mathrm{~kg} \mathrm{~m}^{-2} \mathrm{~s}^{-1}\right)$.

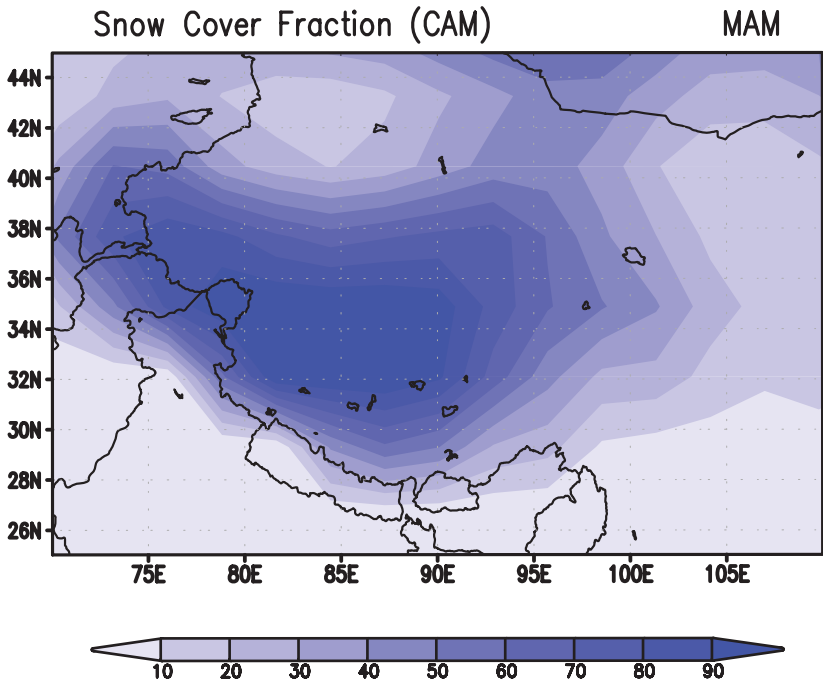

Fig. 2. Snow Cover Fraction (SCF) averaged for March-April-May (MAM) over Tibetan Plateau, (top) MODIS and (bottom) Model.

effect from the Himalaya and Karakoram mountains, the SCF is smaller over the interior area of the TP, although the average elevation is above $4000 \mathrm{~m}$. During summer, snow covered areas are more scattered. The CAM3 remarkably overestimates the SCF, especially over the interior of the TP, due to its apparent inability to capture rainshadow effects of the massive plateau. Due to the coarse spatial resolution, CAM3 fails to capture the complex terrain that generates the observed spatial variability of SCF.

Figure 3a shows the monthly mean SCF and snow water equivalent (SWE) from model and SCF from MODIS. The observation shows around $25-35 \%$ of areas are covered by snow during winter and spring over the TP. The model overpredicts SCF by $20-100 \%$ from November to April, but un-

derpredicts SCF in the warm season probably because the model with coarse horizontal resolution and smoothed terrain fails to capture the perennial snowpack at very high elevation during summer. Although SCF reaches a maximum in winter, snow continues to accumulate so SWE peaks in March until snowmelt.

To investigate the causes of snowpack overestimation over the TP, we compared the simulated monthly precipitation over the TP against three different observational datasets (Fig. 3b). The model substantially overpredicts precipitation during the cold season, which is a primary factor causing the excessive snowpack over the TP in winter and spring.

Figure 3c shows the seasonality of $\mathrm{BC}$ deposition. Model results show that total deposition of $\mathrm{BC}$ is mainly $(>80 \%)$ contributed by wet deposition partly because of the finer size and longer lifetime of $\mathrm{BC}$, which is consistent with other model studies (Textor et al., 2006). Overall the seasonal variation of $\mathrm{BC}$ deposition is not very large. It should be noted that aerosol deposition is not linearly correlated with aerosol concentration in the atmosphere, i.e., a higher (lower) BC concentration in the atmosphere does not necessarily mean a higher (lower) BC deposition on the ground because precipitation and cloud control wet removal, and boundary layer structure and land surface properties affect dry deposition.

Measurements studies show that maximum concentrations of $\mathrm{BC}$ occur during the pre-monsoon season, while minima appear during the monsoon and post-monsoon period for the coarse mass (Marinoni et al., 2010; Decesari et al., 2010; Bonasoni et al., 2010). The lower BC content in the 
atmosphere measured over the TP in the monsoon season is probably due to the frequent and rapid washout process (Marinoni et al., 2010), which implies a possible higher wet deposition in the summer. In other words, removal rate is probably higher and aerosol lifetime is probably shorter in the rainy season. It should be noted that measurements are only made over the southern slope of Himalayas, but the model results shown in Fig. $3 \mathrm{c}$ and $\mathrm{d}$ are an average over the entire TP. Besides India, emissions from other regions also contribute to the BC over the TP (Ming et al., 2008, 2009). To evaluate the model results, surface measurements of aerosol deposition rather than concentration in the atmosphere are urgently needed in a variety of regions over the TP (Kaspari et al., 2011).

BC deposition in the summer is not critical since very little snowpack is left over the TP in the summer from both models and observations (Fig. 3a). The seasonal dependence of snowpack impurities is driven both by seasonality of snow on the ground and timing of aerosol deposition. In Fig. 3c we show the monthly mass of $\mathrm{BC}$ in the top snow layer averaged over areas with snow in the TP. The highest BC mass in snow can be found in late spring because deposition continues in spring but less new snow is accumulated. In addition, snowmelt in spring may decrease snow thickness and increase the $\mathrm{BC}$ mass accumulating over snow since only a fraction of $\mathrm{BC}$ is washed away by the melt water.

In contrast to $\mathrm{BC}$, dust deposition peaks at April, as shown in Fig. 3d, because BC and dust have different sources and lifetime. The magnitude of dry deposition for dust is comparable to that of wet removal due to the larger size of the particles.

Figure 4 shows the simulated annual mean BC content in snow against the measured (Ming et al., 2009). The simulated maximum BC content in snow is over the TP, especially the southern slope with concentrations larger than $100 \mu \mathrm{g} \mathrm{kg}^{-1}$. The southern slope of the Himalayas is directly exposed to Indian emissions and likely receives more $\mathrm{BC}$ than the northern slope via the southwesterly and via the southern branch of the winter westerlies that sweep over the south side of the Himalaya-Hindu Kush range (Kaspari et al., 2007; Xu et al., 2009; Yasunari et al., 2010). As suggested by Menon et al. (2010), the emissions of particulate matter in India have been increasing over the last few decades and are expected to increase in the future due to rapid industrial growth and slower emission control measures.

The simulated $\mathrm{BC}$ content in snow is larger than $25 \mu \mathrm{gg}^{-1}$ over Xingjiang, Western Mongolia and the nearby central Asian countries, indicating that $\mathrm{BC}$ is generating a non-negligible impact on snowpack over these regions. The measured $\mathrm{BC}$ contents in ice core are denoted as circles in Fig. 3 (Xu et al., 2006; Ming et al., 2008, 2009). Because of limited sampling, the spatial distribution of BC content is not well defined by the measurements. The magnitudes of measured BC in snow are between 10 and 110, which are comparable to the simulations in the order of magnitude. It

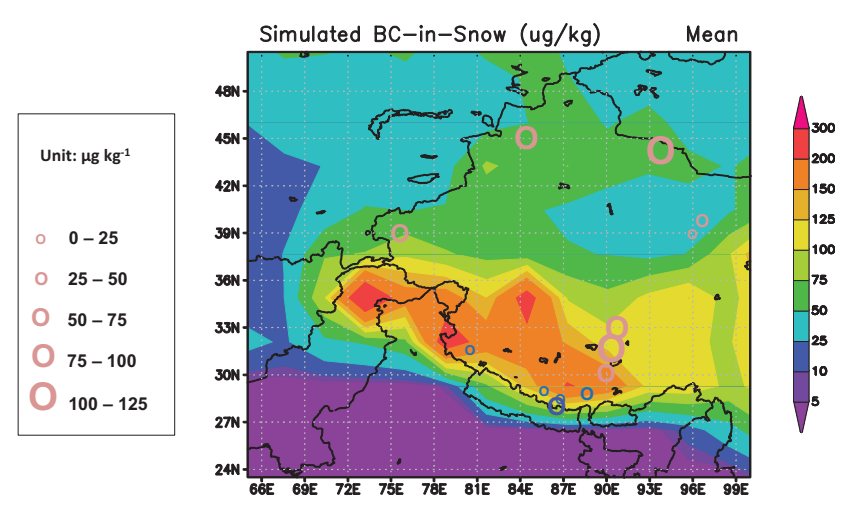

Fig. 4. Simulated annual mean (shaded) against measured (in circle) $\mathrm{BC}$ content in snow (Unit: $\mathrm{ug} \mathrm{kg}^{-1}$ ). The observation is from Xu et al. (2006) and Ming et al. (2009).

should be noted, however, that only an order of magnitude comparison is possible between the simulated and ice corerecorded BC content, because (1) the simulated number represents an average over a big GCM grid cell but the ice core records only a local point measurement; (2) the simulated number is a climatological multiple-year average, but measurements are made during a specific season or year; (3) the simulated number is from the top $2 \mathrm{~cm}$ of snow, whereas the ice core record reflects near-surface and deeper snow. Ming et al. $(2008,2009)$ provided bias and standard deviation for these observations. More in situ measurements for BC-insnow content and $\mathrm{BC}$ deposition are urgently needed in different areas over the TP.

\section{Hydrological effects}

In this section we compare results of the CAM global climate simulations with pre-industrial or present $\mathrm{CO}_{2}$ levels, and with carbonaceous aerosols inactive or active in the atmosphere and snow, to investigate the relative importance of these agents on the surface energy and water budgets over the TP. The following analyses focus on SRFC and equilibrium changes in variables such as temperature, snowpack, and runoff. These variables are the most relevant to the hydrological cycle and water resources.

\subsection{Surface radiative flux changes}

Figure 5 shows the global distribution of SRFC induced by both BC and Dust in snow, averaged annually only when snow is present. From Fig. 5 the maximum SRFC over the TP is apparent. Compared with other snow covered regions, the mean downward solar radiation at the surface is largest over the TP because of its lower latitude (i.e. higher mean solar height angle) and higher altitude (i.e. less extinction by aerosol and cloud). Therefore the SRFC induced by a unit snow albedo change is relatively large over the TP. 


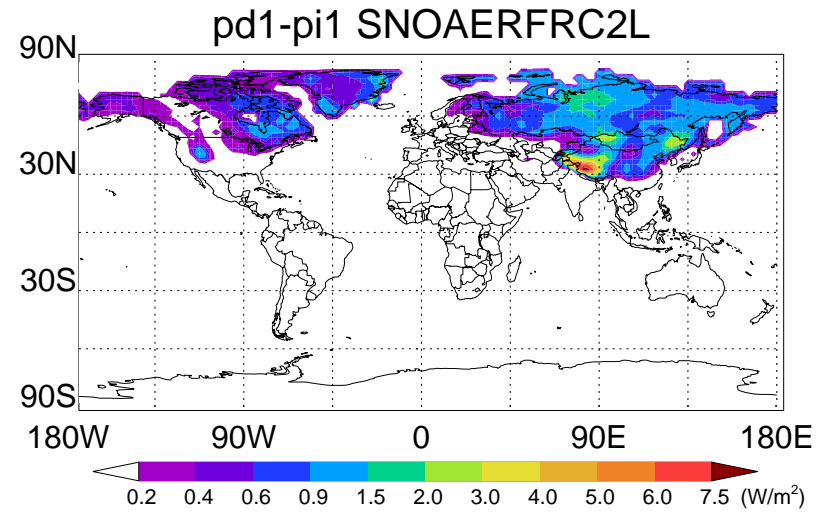

Fig. 5. Global distribution of annual mean surface forcing induced by $\mathrm{BC}+$ Dust in snow, averaged only when snow is present (Unit: $\mathrm{W} \mathrm{m}^{-2}$ ).

Meanwhile, as shown in Fig. 4, aerosol deposition over the TP is significant because (1) the TP is exposed to mineral dust emissions from the central Asian desert/Gobi and large anthropogenic emission sources (e.g. India and central Asia), and (2) the winter westerlies and pre-monsoon circulation with high aerosol content facilitate the transport of pollutants onto the plateau (Xu et al., 2009).

To further look at the effects induced by different types of aerosols, Fig. 6 compares the spatial distribution of surface SRFC induced by fossil fuel and bio-fuel BC only in snow (Fig. 6a) and induced by total BC and dust in snow (Fig. 6b), averaged only when snow is present over Asia during MAM. The SRFC is spatially correlated with the change of snow albedo (Fig. 6c) induced by the presence of $\mathrm{BC}$ in snow. The largest SRFC are over the TP, especially the southwestern TP, where the MAM mean SRFC is larger than $10 \mathrm{~W} \mathrm{~m}^{-2}$ from only fossil fuel and bio-fuel $\mathrm{BC}$, and larger than $13 \mathrm{~W} \mathrm{~m}^{-2}$ when dust is also included in snow. Correspondingly, the snow albedo reductions over the TP reach 0.04 and 0.06, respectively. Another two areas with larger flux changes are located over northeastern China and western Mongolia, where the SRFC is around 3-8 $\mathrm{W} \mathrm{m}^{-2}$ and 3$5 \mathrm{~W} \mathrm{~m}^{-2}$, respectively, for fossil fuel and bio-fuel BC only in snow. When both $\mathrm{BC}$ and dust are considered, the surface flux change over western Mongolia reaches $5-10 \mathrm{~W} \mathrm{~m}^{-2}$, indicating the snowpack over western Mongolia is remarkably affected by mineral dust emitted from the local sources and central Asian countries. The SRFC in other parts of the domain is relatively lower.

Figure 7 shows the monthly changes of SRFC averaged over the TP region (shown as the rectangle in Fig. 6a). As only the fossil fuel and bio-fuel BC in snow is considered, the surface SRFC is larger than $2.5 \mathrm{~W} \mathrm{~m}^{-2}$ from February to May and the maximum value reaches $5 \mathrm{~W} \mathrm{~m}^{-2}$ during April. With a dramatic decrease in snowpack from April to July, the SRFC is very small during the summer and early fall. With both BC and dust (i.e. pd1), the SRFC is larger than pi4 by $1-2 \mathrm{~W} \mathrm{~m}^{-2}$ from January to April and the maximum change is over $6 \mathrm{~W} \mathrm{~m}^{-2}$ during March, indicating the aerosol deposition on snow associated with the winter and early spring dust storm makes an important contribution to the SRFC. The SRFC is very small during summer and fall.

\subsection{Surface air temperature}

Figure 8 shows the spatial distribution of surface air temperature change averaged over MAM for four cases of $\mathrm{CO}_{2}$ increase, $\mathrm{BC}+\mathrm{OM}$ in atmosphere, $\mathrm{BC}$-in-snow, and all of the above, respectively. As the $\mathrm{CO}_{2}$ concentration increases from pre-industrial to present levels, the surface air temperature increases significantly at $90 \%$ level over a majority of areas of Asia. The warming is more than $1^{\circ}$ over the region north of $25^{\circ} \mathrm{N}$, except over the TP, where the temperature increases is slightly smaller than the surrounding areas (not passing the significant test), partly because of cloud feedback (see Fig. 14). The observed warming in the past several decades, however, is larger over the TP than the global average and surrounding regions (Wang et al., 2008), indicating that besides the increasing $\mathrm{CO}_{2}$ concentration other factors need to be considered in explaining the faster warming over the TP.

Aerosols in the atmosphere have more complicated effects on surface air temperature change. On one hand, by absorbing and scattering sunlight, aerosols reduce the solar radiation reaching the surface, thus cooling the skin and surface air. On the other hand, aerosols, especially carbonaceous aerosols such as BC and OM, absorb solar radiation and heat the atmosphere. Thus it is not surprising to see the non-significant and mixed pattern of surface air temperature changes induced by BC and OM in the atmosphere, as shown in Fig. 8b. The remarkable cooling over the TP and India is, however, associated with cloud feedback, which will be discussed in Sect. 4.1 (see Fig. 14b). If we combine the temperature changes induced by both $\mathrm{CO}_{2}$ increase and $\mathrm{BC}+\mathrm{OM}$ in the atmosphere (i.e. Fig. 8a, b), a weaker warming or even cooling trend can be expected over the TP, which implies that only considering $\mathrm{CO}_{2}$ increase and $\mathrm{BC}+\mathrm{OM}$ in the atmosphere may not be enough to explain the accelerated warming over the TP.

Figure $8 \mathrm{c}$ shows the surface air temperature change induced by BC-in-snow. We can see that the surface air temperature increases (significant at $90 \%$ confidence level) by more than $1^{\circ}$ over the TP and northern part of the region. Comparing with Fig. 8b, we see that BC-in-snow exerts stronger warming than direct forcing from carbonaceous aerosols in the atmosphere. From Fig. 8d, temperature increases by $0.5-1.0^{\circ}$ south of $25^{\circ} \mathrm{N}$, but the warming is more significant over the northern part of the region, especially over western China (including the TP), Mongolia, and northeastern China, where the warming is more than $2^{\circ}$. It should be noted that the temperature changes induced by $\mathrm{CO}_{2}$ increase, $\mathrm{BC}+\mathrm{OM}$ 

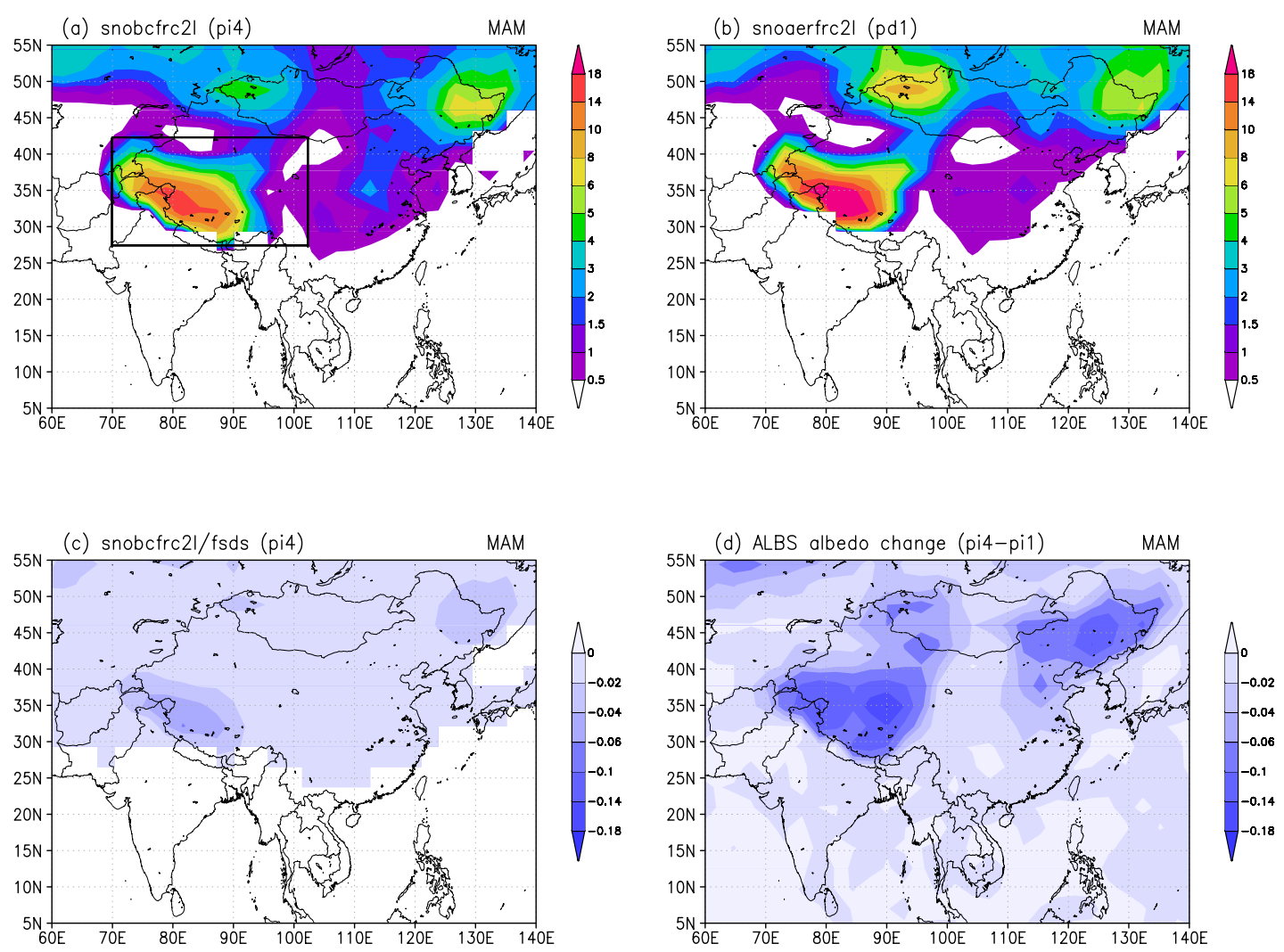

Fig. 6. Spatial distribution of surface forcing (a) induced by BC only in snow in pi4 (unit: $\mathrm{W} \mathrm{m}^{-2}$ ), (b) induced by BC + Dust in snow in pd1 (unit: $\mathrm{W} \mathrm{m}^{-2}$ ), (c) snow albedo change induced by the presence of $\mathrm{BC}$ in snow only (i.e. snobcfrc2l/fsds) in pi4, averaged only when snow is present, and (d) broadband surface albedo change in pi4, which is caused by changes of snow fraction/depth and BC in snow. All are averages for MAM.

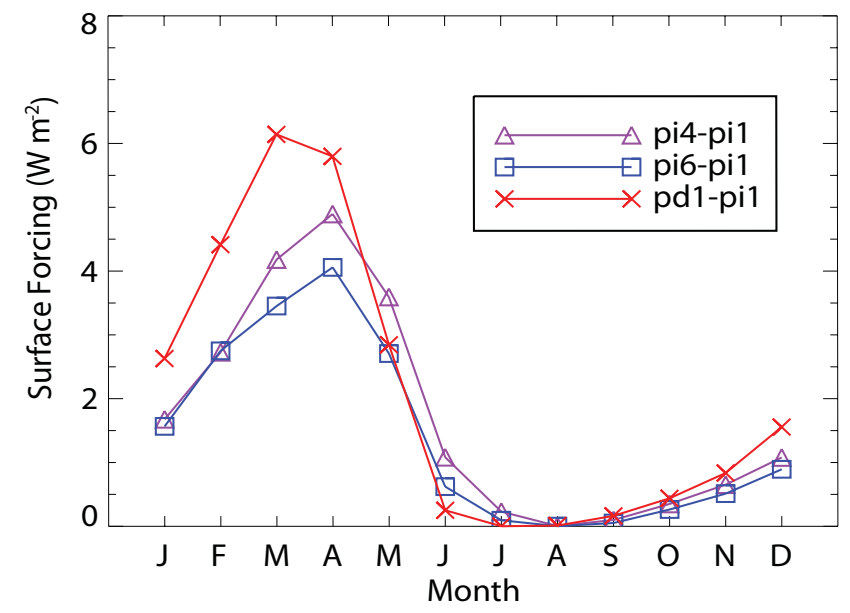

Fig. 7. Monthly surface forcing induced by $\mathrm{BC}$ or $\mathrm{BC}+$ Dust in snow over Tibetan Plateau (pi4-pi1, pi6-pi1, pd1-pi1). in the atmosphere and BC-in-snow, as shown in Fig. 8d, is not a linear combination of the effects induced by each forcing mechanism shown in Fig. 8a-c. The warming over the $\mathrm{TP}$ in pi6 is larger than the linear combination of the warming in the experiments pi2, pi3 and pi4 due to the interactions between aerosol-induced changes in surface albedo, atmospheric absorption, and climate feedback.

Figure 9 shows the seasonal changes of surface air temperature averaged over the TP for each case compared to the control simulation pi1. For the case of the $\mathrm{CO}_{2}$ increase (pi2pi1), the temperature generally increases by around $1.0^{\circ}$ due to the well-known greenhouse effect. The warming reaches a maximum in March and April, probably related to the snow albedo feedback, but overall the seasonal variability of warming is not significant, except for a minimum warming in June. For the case of BC and OM in the atmosphere (pi3-pi1), because of the competing effects previously mentioned, it is not surprising to see the temperature increasing in some months and decreasing in others, and the range of temperature changes is less than $1^{\circ}$. For the case of BC-insnow (pi4-pi1), the temperature increases by $0.7-1.0^{\circ}$ over the TP during spring and summer. When all three effects are included in the simulation (pi6-pi1), the mean temperature 

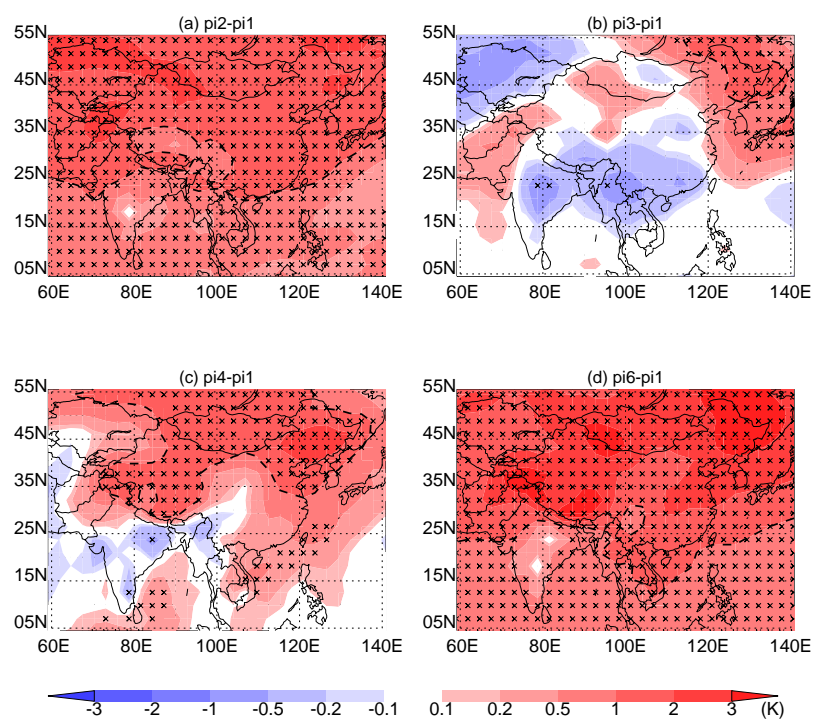

Fig. 8. Spatial distribution of surface air temperature change averaged for MAM for pi2-pi1 (a, induced by $\mathrm{CO}_{2}$ increase), pi3-pi1 (b, induced by BC + OM in atmosphere), pi4-pi1 (c, induced by BC in snow), and pi6-pil (d, induced by $\mathrm{CO}_{2}$ increase $+\mathrm{BC}+\mathrm{OM}$ in atmosphere + BC-in-snow), respectively. Unit: K. Dash contour line is for $1^{\circ}$. Regions passing the $90 \%$ significance level are highlighted by cross.

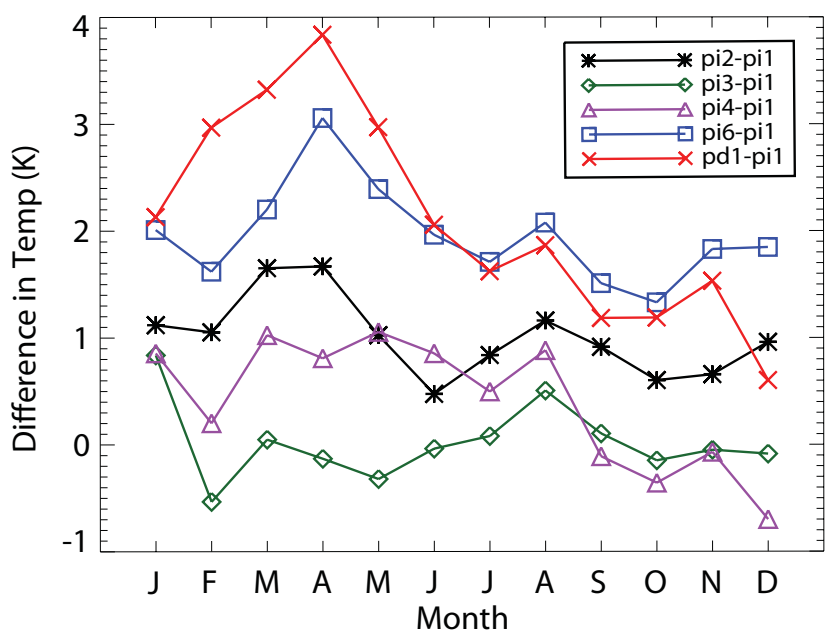

Fig. 9. Monthly surface air temperature differences between (pi2, pi3, pi4, pi6, pd1) and pi1 averaged over Tibetan Plateau (Unit: K).

increases by around $2^{\circ}$ over the TP, with a maximum warming of $3^{\circ}$ on April. With the addition of dust and biomass burning $\mathrm{BC}$, more seasonal variation of temperature change is seen, with a maximum warming of $4^{\circ}$ in April and cooling from April to December. The mean temperature over the TP increases by around $2.9^{\circ}$ for January-June and increases by around $1.3^{\circ}$ for July-December.
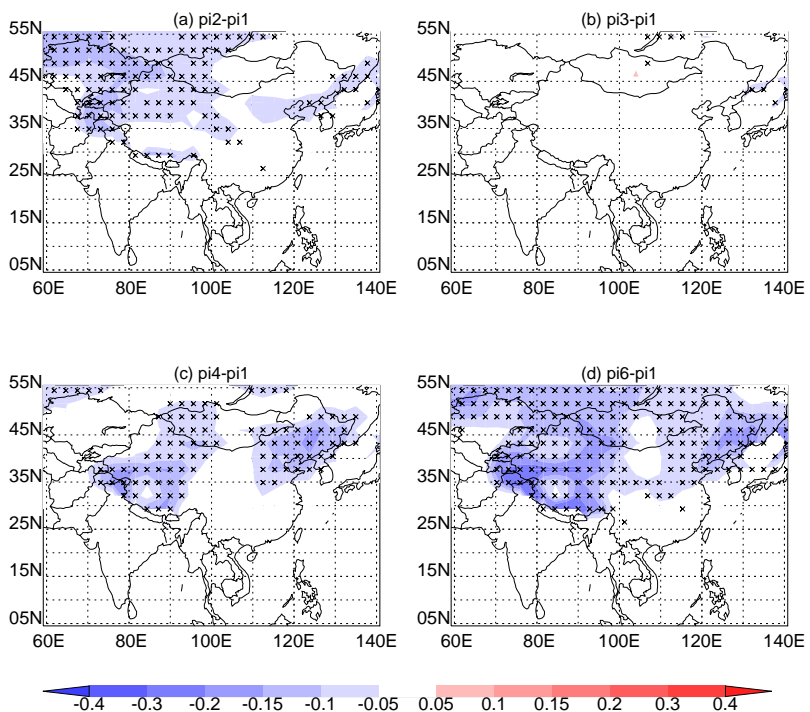

Fig. 10. Same as Fig. 8 but for snow cover fraction (SCF, $0-1)$.

\subsection{Snowpack}

Figure 10 shows the spatial distribution of MAM SCF change for the different sensitivity experiments (pi2, pi3, pi4 and pi6, as discussed), relative to the control (pi1). With $\mathrm{CO}_{2}$ forcing (Fig. 10a), the SCF decreases significantly by $0.05-0.15$ (absolute) over the northwestern part of the region. Over the TP, only a small SCF reduction can be found over the southern slope of the plateau. The SCF changes are very small over other regions. For the case of atmospheric $\mathrm{BC}$ and $\mathrm{OM}$ (Fig. 10b), the SCF change is negligible. Overall, the effects of $\mathrm{CO}_{2}$ increase and atmospheric $\mathrm{BC}+\mathrm{OM}$ on snowpack are small over the TP, suggesting that these may not be the primary factors causing faster melting of the glaciers over the TP. For the case of BC-in-snow, as a result of the increase in net solar heating at the surface, there are significant reductions in snowpack over the TP as shown in Fig. 10c. Maximum reductions of SCF are over the western and southern TP. The reduction of SCF is also significant over northeastern china, a heavy-industrialized area (Huang et al., 2010). When $\mathrm{CO}_{2}$ forcing, $\mathrm{BC}+\mathrm{OM}$ in the atmosphere, and $\mathrm{BC}-$ in-snow are all considered (Fig. 10d), a more and significant reduction of SCF can be found over the northern part of region. The larger reductions in SCF are over western China, with the maximum reduction of SCF around $0.2-0.3$ over the western and southern part of the TP. The pattern of the mean snow water equivalent (SWE) changes (not shown) is generally consistent with that of SCF.

Figure 11 shows the seasonal changes of SCF and SWE averaged over the TP for the five cases. Remarkable changes in snowpack occur between February and June, and the changes are very small for July-October. For $\mathrm{CO}_{2}$ increase (pi2-pi1), the seasonal cycle of snowpack change is distinct, 

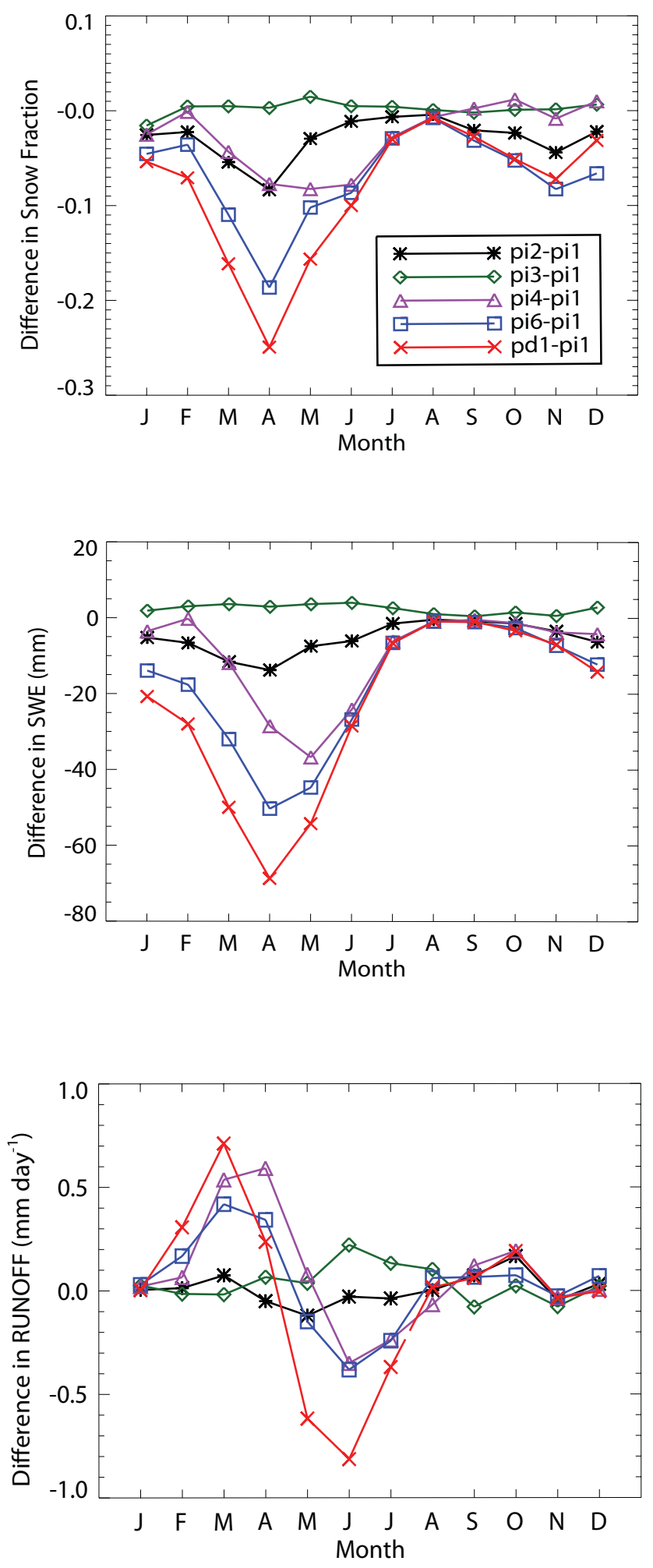

Fig. 11. Same as Fig. 9 but for snow cover fraction (top), snow water equivalence (SWE) (middle, Unit: $\mathrm{mm}$ ) and runoff (bottom, Unit: $\mathrm{mm} \mathrm{day}^{-1}$ ). with the maximum changes in both SCF and SWE occurring in April (0.08 and $13 \mathrm{~mm}$, respectively). For BC and $\mathrm{OM}$ in the atmosphere (pi3-pi1), the snowpack changes are very small throughout the year, which is consistent with the temperature change shown in Fig. 9. For BC-in-snow (pi4pi1), an apparent seasonal cycle can be seen in both SCF and SWE, with a maximum reduction in May, around one month later than the maximum surface RF. The May reductions in SCF and SWE are 0.09 and $35 \mathrm{~mm}$, respectively. The warmer temperatures induced by $\mathrm{CO}_{2}$ increase and $\mathrm{BC}$-in-snow may lead to a greater percentage of precipitation coming in the form of rain rather than snow, resulting in less snow accumulation during the peak snow season. Meanwhile, warmer surface temperatures speed up snowmelt during late winter and spring. Driven by reduced snow accumulation in the winter and increased snowmelt in spring, SWE reduction reaches a maximum in late spring.

When $\mathrm{CO}_{2}$ increase, $\mathrm{BC}+\mathrm{OM}$ in the atmosphere and $\mathrm{BC}-$ in-snow are all included (pi6-pi1), we can find increased amplitude of seasonal cycle in both SCF and SWE. The maximum reduction occurs in April -0.18 for SCF and $50 \mathrm{~mm}$ for SWE. With the dust and biomass burning BC included (pd1-pi1), the pattern of seasonal variation for the snowpack change remains similar to that of pi6-pi1 but with a larger magnitude, and the maximum reduction occurring in April reaches 0.25 for SCF and $70 \mathrm{~mm}$ for SWE.

\subsection{Runoff}

The runoff resulting from snowmelt on the TP is an important water source for the rivers originating in the TP. Figure 11 also shows the seasonal cycle of runoff averaged over the TP for the five cases. The total runoff is mainly controlled by precipitation and snowmelt over the TP. For the $\mathrm{CO}_{2}$ increase, although warming increases snowmelt in spring, runoff changes are very minor in spring and other months because MAM precipitation decreases. For $\mathrm{BC}+\mathrm{OM}$ in the atmosphere, the runoff changes are minor, which is consistent with the small change in temperature and snowpack properties throughout the year. For pi4, pi6 and pd1, with the BC-in-snow effect included, the runoff generally increases during late winter and early spring but decreases during late spring and early summer. When all three effects are included (pd1-pi1), the runoff increases by around $0.44 \mathrm{~mm}$ per day during February-March-April and decreases by around $0.57 \mathrm{~mm}$ per day during May-June-July, with a maximum increase of $0.72 \mathrm{~mm}$ per day in March and a maximum reduction of $0.82 \mathrm{~mm}$ per day in June. As discussed in Sect. 3.3, the warmer temperature may accelerate snowmelt and cause a greater percentage of precipitation to come in the form of rain rather than snow, both of which contribute to more runoff during late winter and early spring. Because less snowpack accumulates during winter, the snow line recedes more quickly in the perturbed simulations with BC-in-snow 
included, so the runoff from snowmelt is reduced during late spring and early summer.

\subsection{Snow albedo feedback process}

In Sect. 3.1, we discussed the correlation between the surface SRFC and snow albedo change. The snow albedo changes shown in Fig. $6 \mathrm{c}$ are albedo values averaged over areas when snow is present so they represent the instantaneous effects induced by the presence of aerosols in snow. Figure $6 \mathrm{~d}$ shows the spatial distribution of broadband surface albedo change averaged for MAM for pi4. This surface albedo change is a weighted average of the albedo over snow/ice and non-snow covered areas within each GCM grid cell. It is affected not only by the impurity of snow but also by snow fraction and depth. Since the albedo changes in Fig. 6d represent the difference in surface albedo between the equilibrium climate simulations with and without the BC-in-snow effect, they include the changes of snow fraction and depth resulting from the full climate feedback.

The albedo changes for $\mathrm{CO}_{2}$ increase and $\mathrm{BC}+\mathrm{OM}$ in atmosphere are found to be very small (less than 0.05) over the entire region (not shown). With the BC-in-snow added, the albedo reduction (Fig. 6d) reaches $0.08-0.20$ over the TP and northeastern China, and is much larger than the snow albedo change shown in Fig. 6c. The BC-in-snow induced warming reduces snow fraction and depth, both contributing to the decrease of grid cell mean albedo. When $\mathrm{CO}_{2}$ increase, $\mathrm{BC}+\mathrm{OM}$ in the atmosphere and $\mathrm{BC}$-in-snow are all included, the albedo reduction $(0.12-0.20)$ becomes more significant over the TP (not shown). However, we caution that in regions where there is excessive snow cover in the control simulation, there is greater potential for snow cover loss and hence albedo change could be overestimated.

In summary, the $\mathrm{BC}$-induced decrease in snow albedo causes the land surface to absorb more solar radiation, increasing the skin and air temperatures. As a result of the perturbed SRFC and warming, snow depth and fraction decrease can further reduce the albedo over partially or entirely snow covered areas. As discussed by Qian et al. (2009a), this positive feedback process is initiated by the $\mathrm{BC}$ deposition on snow which can be illustrated as: $\mathrm{BC}$ deposited on snow $\rightarrow$ reduced snow albedo $\rightarrow$ increased surface net solar radiation $\rightarrow$ skin and air warming $\rightarrow$ snow fraction and depth reduced $\rightarrow$ further reduced surface albedo.

\subsection{Snowmelt efficacy}

Hansen et al. (2005) define "the efficacy of a climate forcing" as the global mean temperature change per unit forcing produced by the forcing agent relative to the response produced by a standard $\mathrm{CO}_{2}$ forcing from the same initial climate state. They estimated a global radiative forcing induced by BC-in-snow of $+0.10( \pm 0.10) \mathrm{W} \mathrm{m}^{-2}$, with an efficacy of 1.7. Here we define "the snowmelt efficacy" as the snowpack
Month

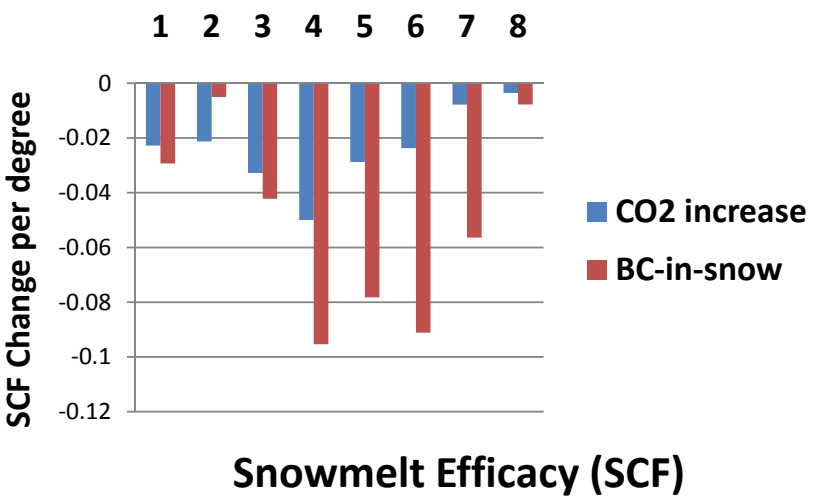

Month

$\begin{array}{llllllll}1 & 2 & 3 & 4 & 5 & 6 & 7 & 8\end{array}$

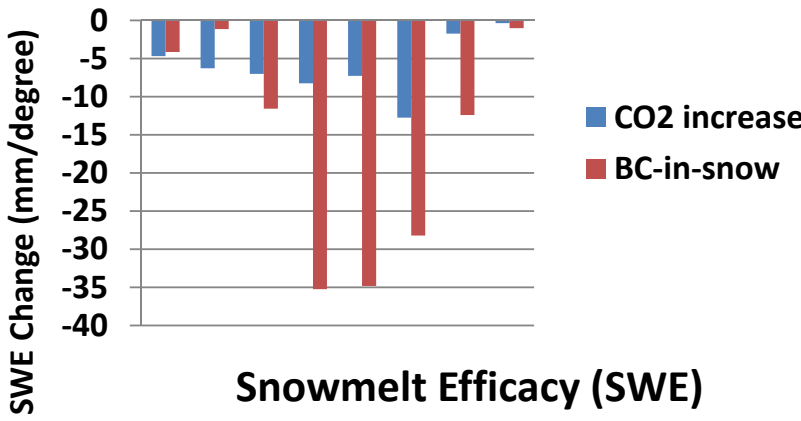

Fig. 12. Ratios of SCF (top) and SWE (bottom) changes against per unit degree of warming induced by $\mathrm{CO}_{2}$ increase and $\mathrm{BC}$-in-snow, respectively, from January to August.

(e.g. SWE or SCF) reduction per unit degree of warming induced by the forcing agent. It should be noted this is not a strict definition since some of temperature changes is caused by snowmelt itself due to the positive feedback as described.

It is interesting to note that the snowpack reduction induced by BC-in-snow is more significant than that induced by $\mathrm{CO}_{2}$ increase in most months (Fig. 11), although the surface air warming induced by $\mathrm{CO}_{2}$ increase is larger than that induced by BC-in-snow in all months except for June (see Fig. 9). Figure 12 compares the SCF and SWE changes per unit degree of (equilibrium) warming induced by $\mathrm{CO}_{2}$ increase and BC-in-snow from January to August, respectively. The snowmelt efficacy induced by BC-in-snow is 1-3 times larger for SCF and 2-4 times larger for SWE than induced by $\mathrm{CO}_{2}$ increase during April-July. Greater snowmelt efficacy for BC-in-snow follows from the forcing depositing additional solar energy directly to snow, and at a time when the net energy into the snowpack is maximal, compared to the $\mathrm{CO}_{2}$ forcing, which transfers thermal energy to snow indirectly, after longwave heating within the atmosphere has equilibrated with other thermal reservoirs within the system. 

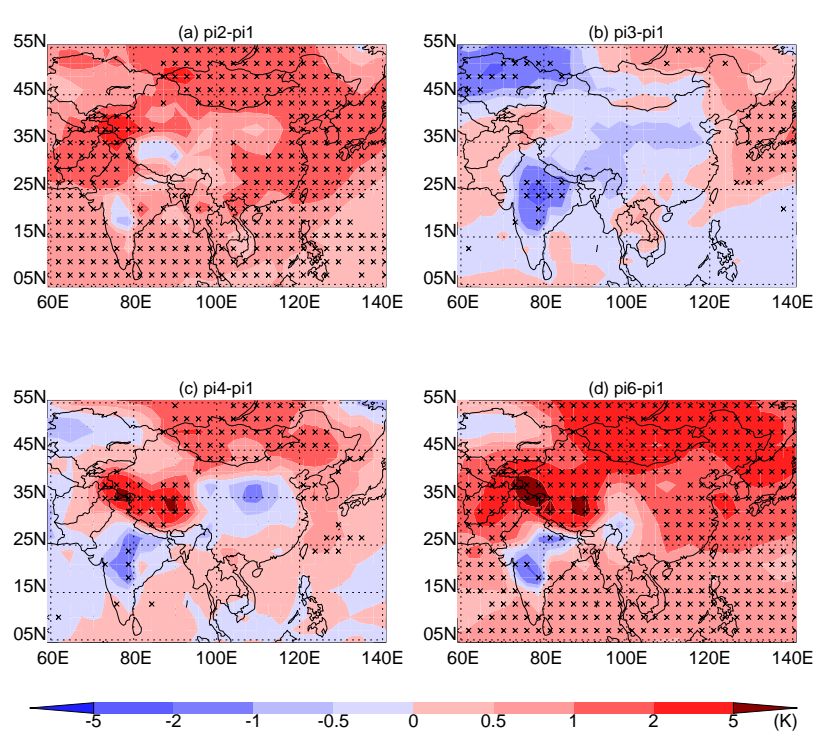

Fig. 13. Spatial distribution of surface skin temperature change averaged for May for pi2-pi1 (a, induced by $\mathrm{CO}_{2}$ increase), pi3-pi1 (b, induced by $\mathrm{BC}+\mathrm{OM}$ in atmosphere), pi4-pi1 (c, induced by BC in snow), and pi6-pi1 (d, induced by $\mathrm{CO}_{2}$ increase $+\mathrm{BC}+\mathrm{OM}$ in atmosphere + BC-in-snow), respectively. (Unit: K). Regions passing the $90 \%$ significance level are highlighted by cross.

\section{Thermal and dynamical effects}

The TP as the Roof of the World or the Third Pole influences the South and East Asian monsoon circulation through its dynamical and thermal forcing. Through the hypothesized EHP effect (Lau and Kim 2006; Lau et al., 2006, 2010), the elevated absorbing aerosols heat the atmosphere over the TP and strengthen local atmospheric circulation, leading to a northward shift of the South Asian monsoon (SAM) rain belt in the late boreal spring. Over East Asia, many studies have found that anomalies of winter or spring snowpack over the TP can affect precipitation in the subsequent summer over East Asia, through strong thermal and dynamical influences on the East Asian monsoon (EAM) circulation (e.g. Wu and Qian, 2003; Qian et al., 2003; Zhang et al., 2004; Ding et al., 2009). The anomalous water flux resulting from snowmelt could increase the soil moisture of the land surface, and thus change the land-air energy exchange and alter the boundarylayer structure and atmospheric circulation. This effect may be time-lagged because of the long memory of soil moisture (Chow et al., 2008). Using the GCM experiments previously discussed, we now compare how $\mathrm{CO}_{2}$ increase, carbonaceous aerosols in the atmosphere, and $\mathrm{BC}$-in-snow affect the SAM and EAM. Our analysis focuses on May for the SAM and July for EAM.
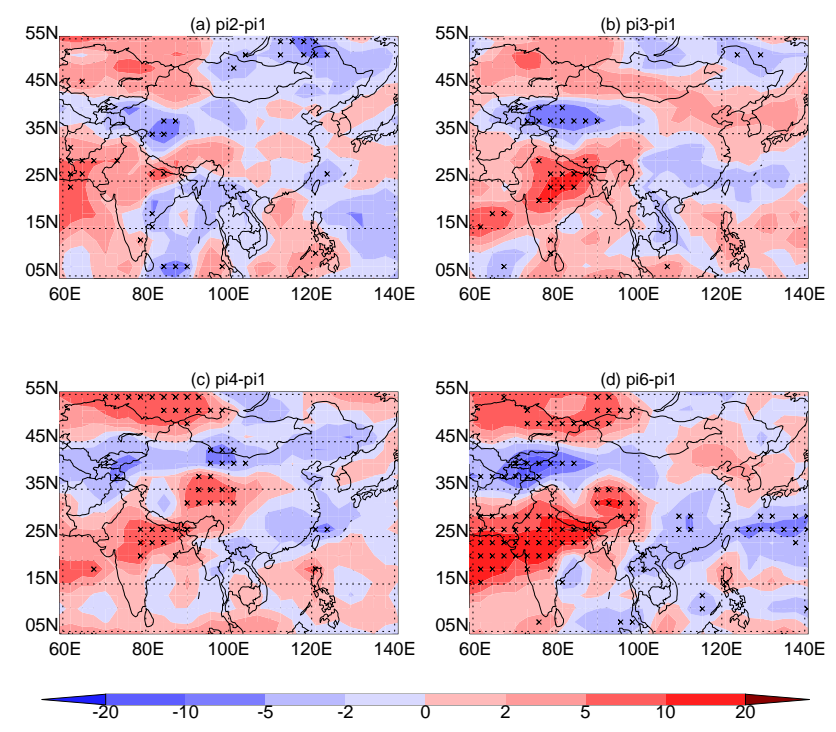

Fig. 14. Same as Fig. 13 but for Total Cloud Fraction (Unit: \%).

\subsection{South Asian Monsoon}

Figure 13 shows the spatial distribution of the May surface skin temperature change for $\mathrm{CO}_{2}$ increase, $\mathrm{BC}+\mathrm{OM}$ in the atmosphere, $\mathrm{BC}$-in-snow, and all of the above, respectively. The increase of $\mathrm{CO}_{2}$ concentration generally increases the surface skin temperature, consistent with the direct atmospheric warming. The corresponding cloud, precipitation and circulation changes are relatively small, probably partly because the warming induced by $\mathrm{CO}_{2}$ increase is more spatially uniform. Atmospheric aerosols, however, significantly (at $90 \%$ confidence level) cool the skin temperature by more than $1^{\circ}$ over central and northern India, mostly because of feedback due to increased total cloud fraction (TCF). Indeed, the TCF increases by $5-20 \%$ at $90 \%$ confidence level over northern India (Fig. 14b), while precipitation also significantly increases by $0.5-2.5 \mathrm{~mm}$ per day over northern India and foothills of the Himalaya (Fig. 15b). These features are consistent with results obtained from simulations with the NASA fvGCM (see Fig. 3 of Lau et al., 2010). They suggest that during boreal spring, the dust and black carbon are transported and accumulated along the foothills of the Himalayas, with the finer particles reaching the higher altitude over the TP region. The elevated dust and black carbon absorb solar radiation and heat the atmosphere around the south slope of the TP, further enhancing the upward motion along the TP during the pre-monsoon season, which increases moisture, cloudiness and deep convection over northern India.

For BC-in-snow, the skin temperature over the TP increases by $1-5^{\circ}$ due to the darkened snow surface and resulting feedback of cloud (Fig. 14b). The skin temperature decreases by $0.5-2^{\circ}$ over central and northern India, where both the TCF and precipitation increase (Figs. $14 \mathrm{c}$ and $15 \mathrm{c}$ ). 

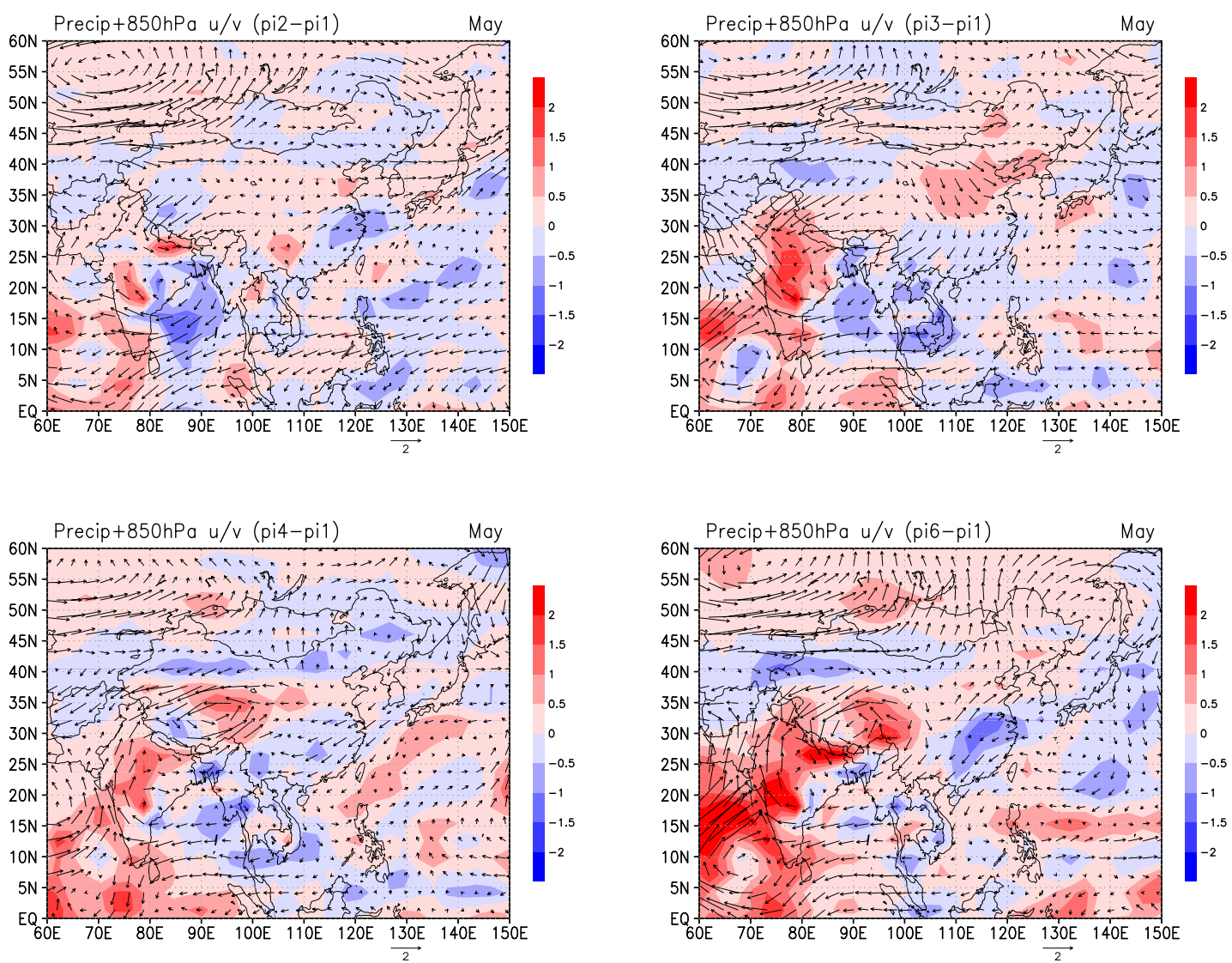

Fig. 15. Spatial distribution of changes for precipitation (shaded, Unit: $\mathrm{mm} \mathrm{day}^{-1}$ ) and $850 \mathrm{hPa}$ wind fields (vector, Unit: $\mathrm{m} \mathrm{s}^{-1}$ ) averaged for May for pi2-pi1 (a, induced by $\mathrm{CO}_{2}$ increase), pi3-pi1 (b, induced by BC + OM in atmosphere), pi4-pi1 (c, induced by BC in snow), and pi6-pil (d, induced by $\mathrm{CO}_{2}$ increase $+\mathrm{BC}+\mathrm{OM}$ in atmosphere $+\mathrm{BC}$-in-snow), respectively.

During late spring and early summer (April through midJune), the increased low-level southwesterly brings in not only additional moisture from the Arabian Sea and Indian Ocean but also aerosols (e.g. dust and BC) from the Indian subcontinent to northern India and the Himalayan foothills, that are possibly deposited over the southern slope of the TP (Yasunari et al., 2010). The enhanced warming over the darkened surface increases the convective instability and spurs deep convection, which further strengthens the low-level southwesterly flow and increases precipitation (Fig. 15c) and cloudiness (Fig. 14c) over central and northern India during the pre-monsoon season. This is a positive feedback process. The increased cloudiness associated with the enhanced lowlevel southwesterly flow and deep convection is, in large part, responsible for the large surface cooling found over central and northern India (Fig. 13c). The aforementioned features comprise the essence of the warming effect of BC-in-snow.

It is interesting to compare the effects of carbonaceous aerosols suspended in the atmosphere and deposited on the snow. While BC and OM in the atmosphere directly absorb sunlight and warm the air, darkened snow surfaces polluted by $\mathrm{BC}$ absorb more solar radiation and increase the skin tem- perature first, and then warm the air above through increased sensible heat flux over the TP. Both effects of carbonaceous aerosols enhance the upward motion of air and spur deep convection along the TP during the pre-monsoon season, resulting in an increase of moisture, cloudiness and convective precipitation over northern India. This implies a stronger and earlier onset of the South Asian summer monsoon. As anticipated, this leads to a larger increase of TCF and precipitation over central and northern India, as well as the eastern TP, when both aerosols in the atmosphere and $\mathrm{BC}$-in-snow are included in the simulation (Figs. 13-15d).

\subsection{East Asian Monsoon}

The TP has long been identified to be important for the onset and evolution of the EAM (e.g. Yeh et al., 1979; Yanai et al., 1992; Chow et al., 2008). Many studies revealed a relationship between the winter or spring snowpack over the TP and precipitation over the mid- and lower-reaches of the YRB and South China in the subsequent summer (Wu and Qian, 2003; Qian et al., 2003; Zhang et al., 2004; Ding et al., 2009). One general conclusion from these studies is that EAM tends to 

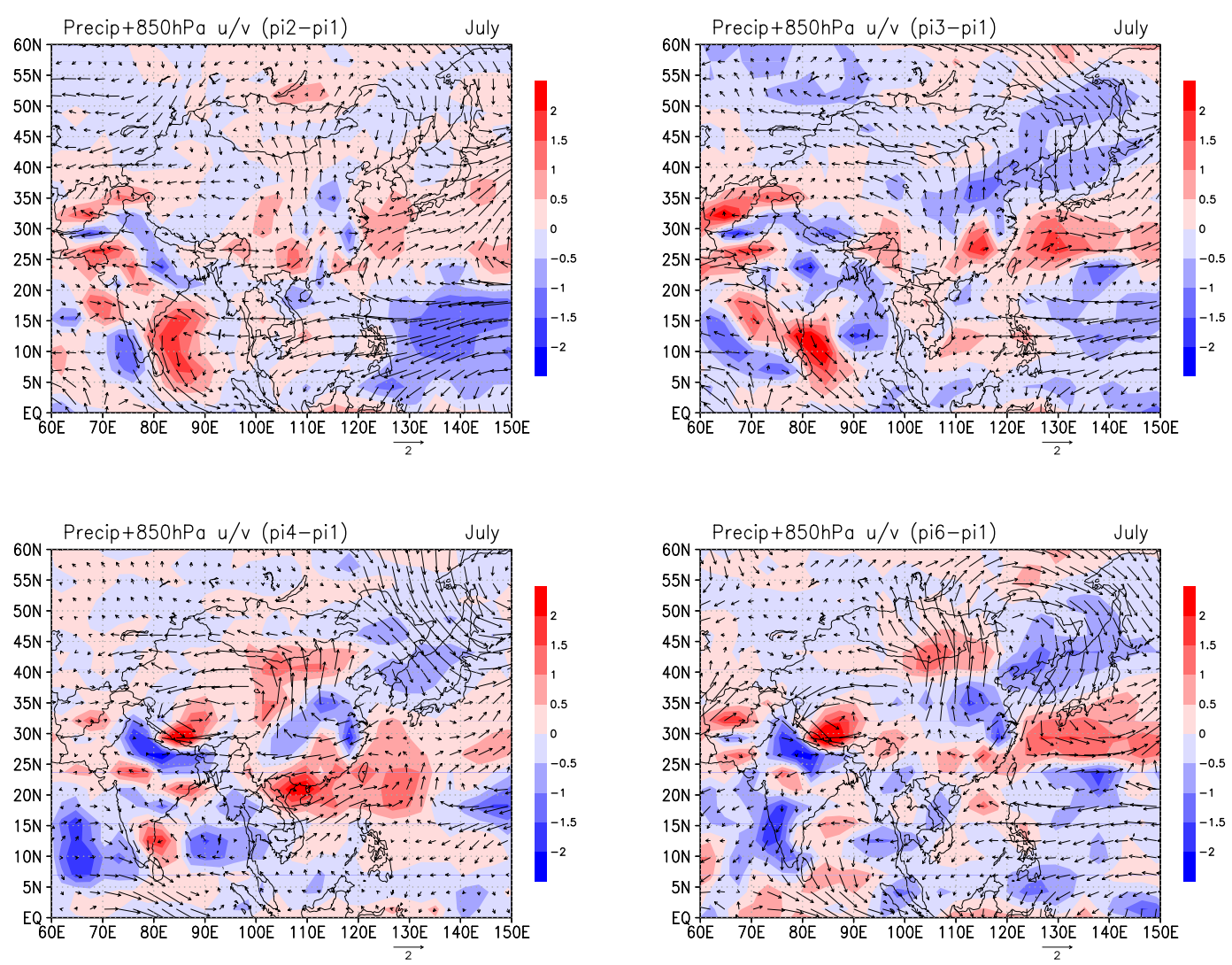

Fig. 16. Same as Fig. 15 but for July.

be weak when snow cover over the TP is large in the previous winter or spring, and associated with the weak EAM is anomalous high summer precipitation over the YRB but low precipitation over North China.

As shown in Fig. 15, the effect of BC-in-snow on the EAM circulation and precipitation is weak over East Asia in May because the onset date of EAM is later than that of SAM. Figure 16 shows, however, that the effect of BC-in-snow on EAM is more remarkable during summer (e.g. July). Although the albedo effect and SRFC induced by BC-in-snow become less important in the summer (Fig. 7) because a large portion of snowpack over the TP disappears by early summer, the change in soil moisture due to snowmelt change can remain large during summer and change surface evaporation and soil thermal properties, and consequently alter the surface heating. Due to the long memory of soil moisture, this effect may be time-lagged. Pielke et al. (1999) suggested that the effects of initial soil moisture anomalies on the subsequent atmospheric circulation could last as long as 12 months.

The energy fluxes between the surface and atmosphere consist of three components: net radiation, sensible heat (SH) and latent heat (LH). Figure 17 shows the seasonal evolution of changes in SH and LH averaged over the TP for the five cases. We can see a remarkable increase in SH dur- ing late spring and early summer induced by the BC-in-snow effect because of the surface warming, with a maximum increase in $\mathrm{SH}$ of $7.5 \mathrm{~W} \mathrm{~m}^{-2}$ in May. Based on the previous estimates of heat sources and sinks over the TP in summer, the surface $\mathrm{SH}$ is often a dominant component of atmospheric heating over the TP, especially over the western part of the TP (Yeh et al., 1979; Ding et al., 2009). The heating contributed by LH is also elevated from March to July (Fig. 17b) because of wetter soil resulting from the increased snowmelt (Fig. 11) and convective precipitation (Fig. 16c) over the TP.

Initiated by BC-in-snow, the increased $\mathrm{SH}$ (because of elevated surface warming) and increased LH (because of wetter soil induced by accelerated snowmelt) both warm the air and enhance deep convection over the TP, resulting in more TCF and precipitation over the TP (Fig. 16), which further increase the soil moisture and LH. This is a time-lagged and positive feedback process. From the spatial patterns of $\mathrm{SH}$ and LH changes induced by BC-in-snow for May and July (not shown), we find that both SH and LH increase by more than $10 \mathrm{~W} \mathrm{~m}^{-2}$ over the central TP in July. Aided by remarkable increases of both LH and SH, the role of the TP as a heat pump is apparently enhanced from spring through summer, i.e. enhancing the thermal contrast between land and ocean and strengthening the EAM in summer. 

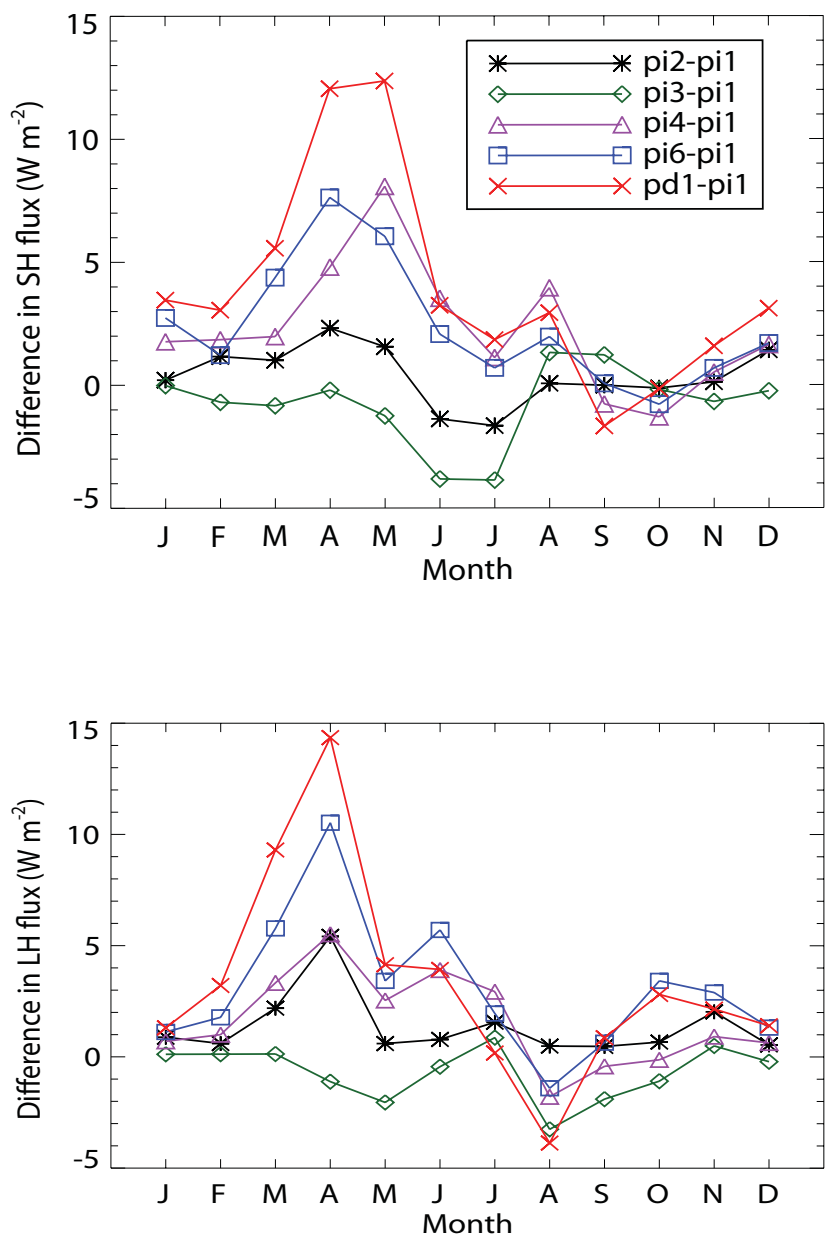

Fig. 17. Same as Fig. 11 but for sensible heat flux SH (top, Unit: $\mathrm{W} \mathrm{m}^{-2}$ ) and latent heat flux LH (bottom, Unit: $\mathrm{W} \mathrm{m}^{-2}$ ).

While the most remarkable changes for circulation and precipitation in May are observed in central and northern India (Fig. 15), the most remarkable changes for precipitation and circulation in July occur over East Asia, especially for the BC-in-snow case (Fig. 16c). Generally, as shown in Fig. 16, in July the impacts of $\mathrm{CO}_{2}$ increase and atmospheric aerosols on circulation and precipitation are smaller over East Asia than the impacts of BC-in-snow. Because of its persistent heating effect over the TP, the impact of $\mathrm{BC}$ in-snow on EAM is most profound in the summer, when the EAM is stronger. Figure 16c shows an increase (at $90 \%$ confidence level) in precipitation of $1-3 \mathrm{~mm}$ per day over southern China and South China Sea, associated with the stronger southwesterly flow over Southeast Asia and the South China Sea. Associated with the strong EAM is more northward moisture transport, which increases precipitation in North China, and reduces precipitation in the central part of East China (i.e. YRB).

As summarized in Fig. 13 of Ding et al. (2009), a stronger summer EAM usually results in anomalously wet, dry, and slightly wet patterns over southern China, the YRB, and northern China, respectively, which is consistent with the near zonal precipitation change pattern induced by $\mathrm{BC}$-insnow (Fig. 16c). Lau et al. (2000) showed that the dominant mode of EAM precipitation variability exhibits a near zonal structure because of the multicellular meridional circulation over East Asia. Both SST forcing (Lau et al., 2000) and snow over the TP (Ding et al., 2009) can modify the strength of EAM, leading to the zonal precipitation anomaly. To further elucidate the linkage between warming over the TP and precipitation in East Asia, Wang et al. (2008) showed that the diabatic heating over the TP could excite two distinct Rossby wave trains that propagate downstream (or eastward) to deform the West Pacific Subtropical High in a way to enhance moisture convergence toward the East Asia subtropical front. This thermal and dynamical linkage between TP warming and East Asia precipitation may explain the enhanced moisture transport from the southwesterly that increases precipitation in South China in our simulations (Fig. 16c).

\section{Summary and discussion}

The Tibetan Plateau (TP) has long been identified to be critical in regulating the Asian monsoon climate and hydrological cycle. The snowpack and glaciers over the TP act as reservoirs to provide fresh water to billions of people in Asian countries through the major rivers originating from the Plateau. Meanwhile heating of the TP has profound thermal and dynamical influences on atmospheric circulation in the Northern Hemisphere. By affecting the energy and water exchange between the land surface and air, anomalous snowpack over the TP will alter the thermal contrast between land and ocean and change the Indian and East Asian Monsoon (EAM) circulation and climate.

As emissions of particulate matter in Asia have been increasing over the last few decades, ice core measurements suggest an increasing trend since 1990 for both BC and OC concentrations deposited to northern TP glaciers. In this study we simulate the deposition and concentration of black carbon (BC) and dust over the TP, and calculate their radiative flux changes and subsequent climatic and hydrological changes. A series of experiments using a global climate model assess the relative impacts of anthropogenic $\mathrm{CO}_{2}$, and carbonaceous particles in the atmosphere and snow, on the snowpack over the TP and Asian monsoon climate and hydrological cycle. The simulations show a large $\mathrm{BC}$ content in snow over the TP. The magnitudes of simulated BC-in-snow are of the same order but overestimated compared to the icecore measurements. With high aerosol content in snow and large incident solar radiation because of lower latitude and higher elevation, the TP exhibits the largest SRFC induced by aerosols (e.g. BC, Dust) in snow compared to any other snow-covered regions in the world. 
The aerosol-induced snow albedo perturbations generate SRFC of $5-25 \mathrm{~W} \mathrm{~m}^{-2}$ during springtime, with maximum change in April and May. Correspondingly, the snow albedo reductions over the TP reach 0.04 and 0.06 , respectively. $\mathrm{BC}$-in-snow increases the surface air temperature by around $1.0^{\circ} \mathrm{C}$ averaged over the TP, similar in magnitude to warming induced by $289-380 \mathrm{ppm} \mathrm{CO}$ increase alone. The atmospheric effect of aerosols alone cools the air above the TP, mostly because of cloud feedback. The BC-in-snow effect significantly reduces the snowpack over the TP, with a distinct seasonal dependence of both SCF and SWE changes (i.e. maximum reduction in May). As a result, the runoff increases during late winter and early spring but decreases during late spring and early summer (i.e. a trend toward earlier melt dates).

In summary, the BC-induced decrease of snow albedo causes the land surface to absorb more solar radiation, increasing the skin and air temperatures and decreasing snow depth and fraction, and further reducing the albedo over the areas with partial or total snow cover. This is a positive feedback process. It is interesting that the snowpack reduction induced by $\mathrm{BC}$-in-snow is larger than that caused by $\mathrm{CO}_{2}$ increase, although the magnitudes of surface air warming induced by the two mechanisms are similar. The snowmelt efficacy, defined as the snowpack reduction per unit degree of equilibrium warming induced by the forcing agent, is 1-4 times larger for $\mathrm{BC}$-in-snow effect than for $\mathrm{CO}_{2}$ increase during April-July, which indicates that BC-in-snow more efficiently accelerates snowmelt process because the increase in net solar radiation is more efficiently used for melting snow.

The TP influences not only the water cycle of the Asian continent through changes in snow and runoff, but it also affects the South and East Asian monsoon through its dynamical and thermal-dynamical forcing, which exert remote influence on precipitation in regions far away from the TP. During boreal spring, driven by southwesterly flow, aerosols are transported to, and accumulate along, the foothills of the Himalayas, with finer particles reaching higher altitudes and some depositing onto snowpack on the TP. While BC and $\mathrm{OM}$ in the atmosphere directly absorb sunlight and warm the air, darkened snow surfaces polluted by BC absorb more solar radiation and increase the skin temperature, which warms the air above through increased sensible heat flux over the TP. Both effects of carbonaceous aerosols enhance the upward motion of air and spur deep convection along the TP during the pre-monsoon season, resulting in an increase in moisture, cloudiness and precipitation over northern India. This implies a stronger and earlier onset of the South Asian summer monsoon.

While most remarkable changes for circulation and precipitation in May are observed in central and northern India, the most remarkable change for precipitation and circulation in July occurs over East Asia as BC-in-snow is included. The BC-in-snow effect shows a more significant impact on East Asia Monsoon than $\mathrm{CO}_{2}$ increase and carbonaceous particles in the atmosphere. Contributed by the significant increase in both $\mathrm{SH}$ associated with warm skin temperature, and LH associated with soil moisture changes (both immediate and lagged), the role of the TP as a heat pump is elevated from spring through summer by increasing the thermal contrast between land and ocean and strengthening the EAM in summer. As a result, both southern China and northern China become wetter, while central China (i.e. Yangtze River Basin) becomes drier, resembling the mode of precipitation variability typically found in China in response to the strength of EAM.

A number of limitations should be taken into account in evaluating the simulation results in this study. The primary one is the significant overestimation of snowpack over the TP, especially in the interior, due to excessive precipitation simulated during the cold season and failure of the coarse resolution GCM to resolve the heterogeneous mountain terrain, as discussed in Sect. 2.2. Consequently, the BC-in-snow content is also overestimated in the model. In the real world, the impact of snow impurity could be larger on the wind-facing steep slopes than at the top of the plateau. In our model, the slope effect on deposition and sun-angle effects on the surface radiative flux are not included, and all the BC and dust effects are plane parallel radiative effects on top of the TP. Thus, the model has likely substantially overestimated the $\mathrm{BC}$ on snow effect, compared to the real world. Because our current results likely only represent the upper limits of snow impurity effect, they should not be extrapolated to the real world.

Although the sensitivity analyses described in this paper provided significant insights on the role of polluted TP snowpack on the hydrological cycle and monsoon climate of Asia, more quantitative assessment of this effect will require improved models and/or higher grid resolution to better simulate snow and aerosol deposition on the TP. As summarized in IPCC (2007), uncertainties and inter-model inconsistency in predicting preciptation are still pretty large among IPCC AR4 GCMs. The confidence in predicting the snowfall is even lower, especially over mountainous regions. Roesch (2006) evaluated the snowpack simulation in a dozen of IPCC AR4 GCMs and found that most GCMs predict excessive snow mass (by 20-100\%) in spring due to excessive snowfall during winter and spring. Thus, common problems in simulating the hydrological cycle in current GCMs pose a critical limitation for assessing aerosol effects on snow and the subsequent impacts.

A second limitation is that the indirect effects of aerosols in the atmosphere are not represented in our simulations. It is well known that besides direct and semi-direct radiative effects, aerosols also have important microphysical effects on clouds and precipitation through their influence on cloud drop nucleation, which affects cloud life time, cloud albedo, and precipitation (Ramaswamy, 2001; Qian et al., 2009b; Jacobson, 2010). With indirect effects included, the hydrological cycle and Asian monsoon may respond in a more 

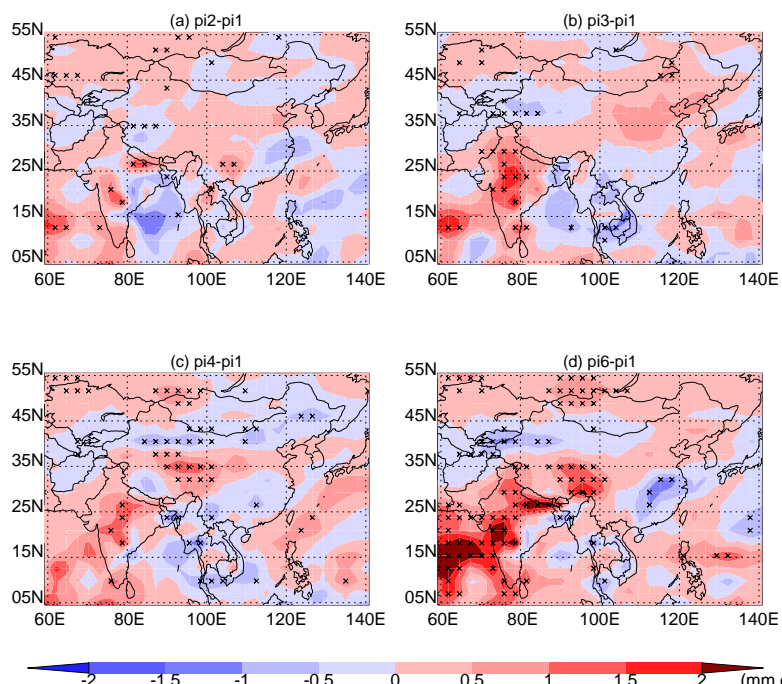

0.5

Fig. A1 Spatial distribution of changes for precipitation (shaded, Unit: $\mathrm{mm} \mathrm{day}^{-1}$ ) averaged for May for pi2-pi1 (a, induced by $\mathrm{CO}_{2}$ increase), pi3-pi1 (b, induced by $\mathrm{BC}+\mathrm{OM}$ in atmosphere), pi4-pi1 (c, induced by $\mathrm{BC}$ in snow), and pi6-pil (d, induced by $\mathrm{CO}_{2}$ increase $+\mathrm{BC}+\mathrm{OM}$ in atmosphere $+\mathrm{BC}$-in-snow), respectively. The regions passing the $90 \%$ significance level are highlighted by cross.

complicated way as cloud, precipitation and monsoon circulation are influenced by aerosols in both India and East Asia.

Third, this study considers the impacts of long-range transported BC on TP snow. Although we included dust in experiment pd1 to achieve a more realistic simulation, the impact of dust alone on the hydrological cycle and climate is not included in this paper partly because the dust in pd1 is included together with BB BC and OM. Dust may in fact be the dominant absorber in the study region, but uncertainties associated with modeling dust are probably even greater than $\mathrm{BC}$, largely because the emissions of dust are prognostically simulated, whereas $\mathrm{BC}$ emissions are prescribed based on bottom-up emission inventories (Bond et al., 2004). Besides the long-range transported dust, many snow surfaces may, however, be primarily darkened by locally derived, coarsegrained dust and sand caused, for example, by local grazing. Glaciers can be significantly darkened by debris and cryoconite, especially in the ablation zone (Takeuchi et al., 2001). Since our estimated BC-in-snow effect on temperature is high or comparable to the observed trends that should include the effects of grazing, debris, and cryoconite, this suggests that our simulated BC-in-snow impacts are likely overestimated.

Finally the goal of this study is to better understand how polluted snow on the TP may affect the hydrological cycle and monsoon climate, and to compare the role of $\mathrm{CO}_{2}$, and aerosol effects in the atmosphere and in snow through sensitivity experiments. We make no attempt to compare the simulated effects with the accelerated warming and glacier re-
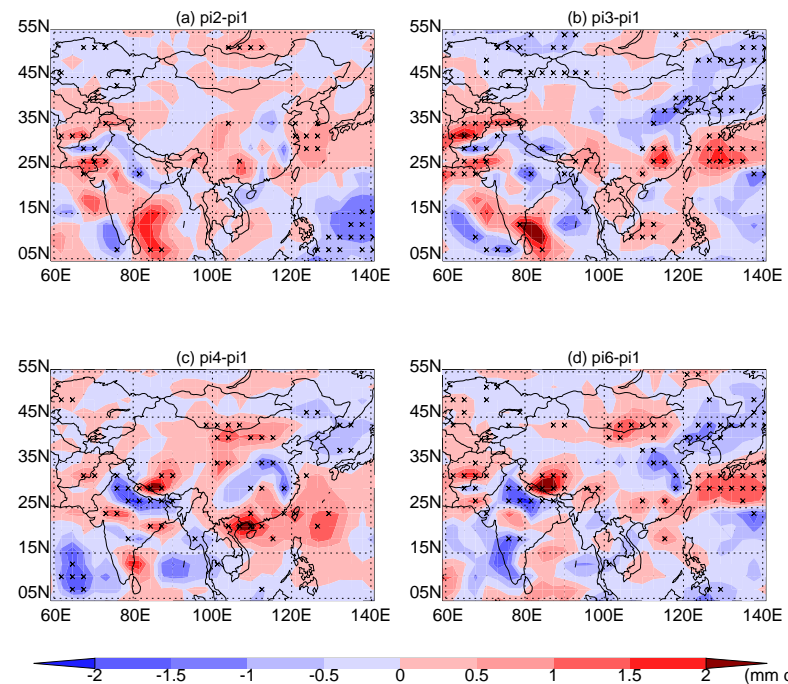

0.5

Fig. A2 Same as Fig. A1 but for July.

treat observed over the TP in past decades. In the real world, many other factors besides snow impurities, carbonaceous aerosols and greenhouse gases induced warming could combine nonlinearly, leading to the accelerated snow/ice melting over the TP. These include active land-use and landcover change (e.g. Cui and Graf, 2009) and slow-evolving large-scale climate variability. Attributing changes in the TP warming and glacial retreat is further complicated when climate feedbacks such as increased sunlight duration from reduced cloudiness, increased water vapor and cloud feedback can play an important role in determining the climate response. More integrated earth system modeling and more reliable observational datasets (including satellite data) are needed to more comprehensively address the accelerated warming and faster glacier retreat over the TP.

Acknowledgements. We thank Jin-Ho Yoon for his internal review and constructive comments. This research is sponsored by the US Department of Energy's Office of Science Biological and Environmental Research under a bilateral agreement with the China Ministry of Science and Technology on regional climate research. Mark Flanner's work in this study is supported by NSF ATM0852775. This study is also partly supported by the DOE Office of Science (BER)'s Cryosphere Project. PNNL is operated for the US DOE by Battelle Memorial Institute under contract DE-AC0676RLO1830.

Edited by: G. McFiggans 


\section{References}

Barnett, T. P., Dumenil, L., Schlese, U., and Roeckner, E.: The effect of Eurasian snow cover on global climate, Science, 239, 504-507, doi:10.1126/science.239.4839.504, 1988.

Barnett, T. P., Dumenil, L., Schlese, U., Roeckner, E., Latif, M.: The effect of Eurasian snow cover on regional and global climate variations, J. Atmos. Sci., 46, 661-685, 1989.

Barnett, T. P., Adam J. C., and Lettenmaier, D. P.: Potential impacts of a warming climate on water availability in snow-dominated regions, Nature, 438, 303-309, doi:10.1038/nature04141, 2005.

Bond, T. C. and Bergstrom, R. W.: Light absorption by carbonaceous particles: An investigative review, Aerosol Sci. Technol., 40(1), 27-67, doi:10.1080/02786820500421521, 2006.

Bond, T. C., Streets, D. G., Yarber, K. F., Nelson, S. M., Woo, J.H., and Klimont, Z.: A technology-based global inventory of black and organic carbon emissions from combustion, J. Geophys. Res., 109, D14203, doi:10.1029/2003JD003697, 2004.

Bond, T. C., Habib, G., and Bergstrom, R. W.: Limitations in the enhancement of visible light absorption due to mixing state, J. Geophys. Res., 111, D20211, doi:10.1029/2006JD00731, 2006.

Bonasoni, P., Laj, P., Marinoni, A., Sprenger, M., Angelini, F., Arduini, J., Bonafè, U., Calzolari, F., Colombo, T., Decesari, S., Di Biagio, C., di Sarra, A. G., Evangelisti, F., Duchi, R., Facchini, MC., Fuzzi, S., Gobbi, G. P., Maione, M., Panday, A., Roccato, F., Sellegri, K., Venzac, H., Verza, GP., Villani, P., Vuillermoz, E., and Cristofanelli, P.: Atmospheric Brown Clouds in the Himalayas: first two years of continuous observations at the Nepal Climate Observatory-Pyramid (5079 m), Atmos. Chem. Phys., 10, 7515-7531, doi:10.5194/acp-10-7515-2010, 2010.

Chow, K. C., Chan, J., Shi, X. L., Liu, Y. M., and Ding, Y. H.: Time-lagged effects of spring Tibetan Plateau soil moisture on the monsoon over China in early summer, Int. J. Climatol., 28, 55-67, 2008.

Cohen J. and Rind, D.: The effect of snow cover on the climate, J. Climate, 4, 689-706, 1991.

Collins, W. D., Rasch, P. J., Eaton, B. E., Khattatov, B., Lamarque, J.-F., and Zender, C. S.: Simulating aerosols using a chemical transport model with assimilation of satellite aerosol retrievals: Methodology for INDOEX, J. Geophys. Res., 106(D7), 73137336, 2001.

Collins, W. D., Bitz, C. M., Blackmon, M. L., Bonan, G. B., Bretherton, C. S., Carton, J. A., Chang, P., Doney, S. C., Hack, J. J., Henderson, T. B., Kiehl, J. T., Large, W. G., McKenna, D. S., Santer, B. D., and Smith, R. D.: The Community Climate System Model Version 3 (CCSM3), J. Climate, 19, 2122-2161, 2006.

Cui, X. F. and Graf, H. F.: Recent land cover changes on the Tibetan Plateau: a review, Climatic Change, 94, 47-61, 2009.

Decesari, S., Facchini, M. C., Carbone, C., Giulianelli, L., Rinaldi, M., Finessi, E., Fuzzi, S., Marinoni, A., Cristofanelli, P., Duchi, R., Bonasoni, P., Vuillermoz, E., Cozic, J., Jaffrezo, J. L., and Laj, P.: Chemical composition of $\mathrm{PM}_{10}$ and $\mathrm{PM}_{1}$ at the highaltitude Himalayan station Nepal Climate Observatory-Pyramid (NCO-P) (5079 m a.s.l.), Atmos. Chem. Phys., 10, 4583-4596, doi:10.5194/acp-10-4583-2010, 2010.

Ding, Y. H., Sun, Y., Wang, Z. Y., Zhu, Y. X., and Song, Y. F.: Inter-decadal variation of the summer precipitation in China and its association with decreasing Asian summer monsoon Part II: Possible causes, Int. J. Climatol., 29, 1926-1944,, 2009.

Flanner, M. G., Zender, C. S., Randerson, J. T., and
Rasch, P. J.: Present-day climate forcing and response from black carbon in snow, J. Geophys. Res., 112, D11202, doi:10.1029/2006JD008003, 2007.

Flanner, M. G., Zender, C. S., Hess, P. G., Mahowald, N. M., Painter, T. H., Ramanathan, V., and Rasch, P. J.: Springtime warming and reduced snow cover from carbonaceous particles, Atmos. Chem. Phys., 9, 2481-2497, doi:10.5194/acp-9-24812009, 2009.

Gautam, R., Hsu, N. C., Lau, K.-M., Tsay, S.-C., and Kafatos, M.: Enhanced pre-monsoon warming over the Himalayan-Gangetic region from 1979 to 2007, Geophys. Res. Lett., 36, L07704, doi:10.1029/2009GL037641, 2009a.

Gautam, R., Hsu, N. C., Lau, K.-M., and Kafatos, M.: Aerosol and rainfall variability over the Indian monsoon region: distributions, trends and coupling, Ann. Geophys., 27, 3691-3703, doi:10.5194/angeo-27-3691-2009, 2009 b.

Hansen, J. and Nazarenko, L.: Soot climate forcing via snow and ice albedos, P. Natl. Acad. Sci. USA, 101(2), 423-428, 2004.

Hansen, J., Sato, M., Ruedy, R., Nazarenko, L., Lacis, A., Schmidt, G. A., Russell, G., Aleinov, I., Bauer, M., Bauer, S., Bell, N., Cairns, B., Canuto, V., Chandler, M., Cheng, Y., Del Genio, A., Faluvegi, G., Fleming, E., Friend, A., Hall, T., Jackmann, C., Kelley, M., Kiang, N., Koch, D., Lean, J., Lerner, J., Lo, K., Menon, S., Miller, R., Minnis, P., Novakov, T., Oinas, V., Perlwitz, Ja., Perlwitz, Ju., Rind, D., Romanou, A., Shindell, D., Stone, P., Sun, S., Tausnev, N., Tresher, D., Wielicki, B., Wong, T., Yao, M., and Zhang, S.: Efficacy of climate forcings, J. Geophys. Res., 110, D18104, doi:10.1029/2005JD005776, 2005.

Hess, M., Koepke, P., and Schult, I.: Optical properties of aerosols and clouds: The software package OPAC, Bull. Am. Meteorol. Soc., 79(5), 831-844, 1998.

Huang, J., Fu, Q., Zhang, W., Wang, X., Zhang, R., Ye, H., and Warren, S. G.: Dust and black carbon in seasonal snow across Northern China, Bull. Am. Meteorol. Soc., doi:10.1175/2010BAMS3064.1, 2010.

Intergovernmental Panel on Climate Change: Climate Change 2007: The Physical Science Basis. Contribution of Working Group I to the Fourth Assessment Report of the Intergovernmental Panel on Climate Change,Solomon, S., Qin, D., Manning, M., Marquis, M., Averyt, K., Tignor, M., Miller, H. L., and Chen, Z., Cambridge Univ. Press, Cambridge, UK, 2007.

Jacobson, M. Z.: Climate response of fossil fuel and biofuel soot, accounting for soot's feedback to snow and sea ice albedo and emissivity, J. Geophys. Res., 109, D21201, doi:10.1029/2004JD004945, 2004.

Jacobson, M. Z.: Short-term effects of controlling fossil-fuel soot, biofuel soot and gases, and methane on climate, Arctic ice, and air pollution health, J. Geophys. Res., 115, D14209, doi:10.1029/2009JD013795, 2010.

Kaspari, S., Mayewski, P. A., Kang, S., Sneed, S., Hou, S., Hooke, R., Kreutz, K. J., Introne, D., Handley, M. J., Maasch, K., Qin, D., and Ren, J.: Reduction in northward incursions of the South Asian Monsoon since $\sim 1400$ AD inferred from a Mt. Everest ice core, Geophys. Res. Lett., 34, L16701, doi:10.1029/2007GL030440, 2007.

Kaspari, S. D., Schwikowski, M., Gysel, M., Flanner, M. G., Kang, S., Hou, S., and Mayewski, P. A.: Recent Increase in Black Carbon Concentrations from a Mt. Everest Ice Core Spanning 1860-2000 AD, Geophys. Res. Lett., 38, L04703, 
doi:10.1029/2010GL046096, 2011.

Lau, K.-M. and Kim, K.-M.: Observational relationships between aerosol and Asian monsoon rainfall, and circulation, Geophys. Res. Lett., 33, L21810, doi:10.1029/2006GL027546, 2006.

Lau, K. M. and Kim, K. M.: Comments on the paper " Elevated Heat pump" hypothesis for the aerosol-monsoon hydroclimate link: "Grounded" in Observations? By Nigam and Bollassino, J. Geophys. Res., doi:10.1029/2010JD014800, in press, 2011.

Lau, K.-M., Kim, K.-M., and Yang, S.: Dynamical and Boundary Forcing Characteristics of Regional Components of the Asian Summer Monsoon, J. Climate, 13, 2461-2482, 2000.

Lau, K. M., Kim, M. K., and Kim, K. M.: Asian monsoon anomalies induced by aerosol direct forcing: the role of the Tibetan Plateau, Clim. Dyn., 26, 855-664, 2006.

Lau, K.-M., Kim, M. K., Kim, K.-M., and Lee, W. S.: Enhanced surface warming and accelerated snow melt in the Himalayas and Tibetan Plateau induced by absorbing aerosols, Environ. Res. Lett., 5, 025204 doi:10.1088/1748-9326/5/2/025204, 2010.

Liu, X. D. and Chen, B. D.: Climatic warming in the Tibetan Plateau during recent decades, Int. J. Climatol., 20, 1729-1742, 2000.

Mahowald, N. M., Muhs, D. R., Levis, S., Rasch, P. J., Yoshioka, M., Zender, C. S., and Luo, C.: Change in atmospheric mineral aerosols in response to climate: Last glacial period, preindustrial, modern, and doubled carbon dioxide climates, J. Geophys. Res., 111, D10202, doi:10.1029/2005JD006653, 2006.

Manabe, S. and Terpstra, T. B.: The effects of mountains on the general circulation of the atmosphere as identified by numerical experiments, J. Atmos. Sci., 31, 3-42, 1974.

Marinoni, A., Cristofanelli, P., Laj, P., Duchi, R., Calzolari, F., Decesari, S., Sellegri, K., Vuillermoz, E., Verza, G. P., Villani, P., and Bonasoni, P.: Aerosol mass and black carbon concentrations, a two year record at NCO-P (5079 m, Southern Himalayas), Atmos. Chem. Phys., 10, 8551-8562, doi:10.5194/acp-10-85512010, 2010

Meehl, G. A. and Stocker, T. F.: Global climate projections, in: Climate Change 2007: The Physical Science Basis: Fourth Assessment Report of the Intergovernmental Panel on Climate Change, edited by: Solomon, S., Qin, D., Manning, M., Marquis, M., Averyt, K., Tignor, M., Miller, H. L., and Chen, Z., Cambridge Univ. Press, Cambridge, UK, 2007.

Menon, S., Koch, D., Beig, G., Sahu, S., Fasullo, J., and Orlikowski, D.: Black carbon aerosols and the third polar ice cap, Atmos. Chem. Phys., 10, 4559-4571, doi:10.5194/acp-10-4559-2010, 2010.

Ming, J., Cachier, H., Xiao, C., Qin, D., Kang, S., Hou, S., and $\mathrm{Xu}, \mathrm{J}$.: Black carbon record based on a shallow Himalayan ice core and its climatic implications, Atmos. Chem. Phys., 8, 13431352, doi:10.5194/acp-8-1343-2008, 2008.

Ming, J., Xiao, C., Cachier, H., Qin, D., Qin, X., Li, Z., and Pu, J.: Black Carbon $(\mathrm{BC})$ in the snow of glaciers in west China and its potential effects on albedos, Atmos. Res., 92(1), 114-123, 2009.

Nigam, S. and Bollasina, M.: "Elevated heat pump" hypothesis for the aerosol-monsoon hydroclimate link: "Grounded" in observations?, J. Geophys. Res., 115, D16201, doi:10.1029/2009JD013800, 2010.

Niu, G.-Y. and Yang, Z.-L.: An observation-based formulation of snow cover fraction and its evaluation over large North American river basins, J. Geophys. Res., 112, D21101,
doi:10.1029/2007JD008674, 2007.

Ogren, J. A. and Charlson, R. J.: Elemental carbon in the atmosphere: Cycle and lifetime, Tellus, 35B, 241-254, 1983.

Painter, T. H., Barrett, A. P., Landry, C. C., Neff, J. C., Cassidy, M. P., Lawrence, C. R., McBride, K. E., and Farmer, G. L.: Impact of disturbed desert soils on duration of mountain snow cover, Geophys. Res. Lett., 34, L12502, doi:10.1029/2007GL030284, 2007.

Prasad, A. K., Yang, K.-H. S., El-Askary, H. M., and Kafatos, M.: Melting of major Glaciers in the western Himalayas: evidence of climatic changes from long term MSU derived tropospheric temperature trend (1979-2008), Ann. Geophys., 27, 4505-4519, doi:10.5194/angeo-27-4505-2009, 2009.

Pielke, R. A., Liston, G. E., Eastman, J. L., Lu, L., and Coughenour, M.: Seasonal weather prediction as an initial value problem, J. Geophys. Res., 104, 19463-19479, 1999.

$\mathrm{Pu}, \mathrm{Z}$. X. and Xu, L.: MODIS/Terra observed snow cover over the Tibet Plateau: distribution, variation and possible connection with the East Asian Summer Monsoon (EASM), Theor. Appl. Climatol., 97, 265-278, doi:10.1007/s00704-008-0074-9, 2009.

Qian, Y. and Leung, L. R.: A long-term regional simulation and observations of the hydroclimate in China, J. Geophys. Res., 112 D14104, doi:10.1029/2006JD008134, 2007.

Qian, Y. F., Zheng, Y. Q., Zhang, Y., and Miao, M. Q.: Responses of China's summer monsoon climate to snow anomaly over the Tibetan Plateau, Int. J. Climatol., 23, 593-613, doi:10.1002/joc.901, 2003.

Qian, Y., Kaiser, D., Leung, L. R., and Xu, M.: More frequent cloud-free sky and less surface solar radiation in China?, Geophys. Res. Lett., 33, L01812, doi:10.1029/2005GL024586, 2006.

Qian, Y., Wang, W., Leung, L. R., and Kaiser, D. P.: Variability of solar radiation under cloud-free skies in China: The role of aerosols, Geophys. Res. Lett., 34, L12804, doi:10.1029/2006GL028800, 2007.

Qian, Y., Gustafson Jr., W. L., Leung, L. R., and Ghan, S. J.: Effects of soot-induced snow albedo change on snowpack and hydrological cycle in western United States based on Weather Research and Forecasting chemistry and regional climate simulations, J. Geophys. Res., 114, D03108, doi:10.1029/2008JD011039, 2009a.

Qian, Y., Gong, D., Fan, J., Leung, L. R., Bennartz, R., Chen, D., and Wang W.,: Heavy pollution suppresses light rain in China: observations and modeling, J. Geophys. Res., 114, D00K02, doi:10.1029/2008JD011575, 2009b.

Qin, D. H., Liu, S. Y., and Li, P. J.: Snow cover distribution, variability, and response to climate change in western China, J. Clim., 19(9), 1820-1833, 2006.

Qu, X. and Hall, A.: Assessing snow albedo feedback in simulated climate change, J. Clim., 19, 2617-2630, doi:10.1175/JCLI3750.1, 2006.

Ramanathan, V., Ramana, M. V., Roberts, G., Kim, D., Corrigan, C., Chung, C., and Winker, D.: Warming trends in Asia amplified by brown cloud solar absorption, Nature, 448, 575-578, doi:10.1038/nature06019, 2007.

Ramaswamy, V.: Radiative forcing of climate change, in: Climate Change 2001: The Scientific Basis: Contribution of Working Group I to the Third Assessment Report of the Intergovernmental Panel on Climate Change, Houghton, J. T., Ding, Y., Griggs, D. J., Noguer, M., Linden, P. J., Dai, X., Maskell, K., and Johnson, 
C. A.,, 349-416, Cambridge Univ. Press, Cambridge, UK, 2001.

Rasch, P. J., Barth, M. C., Kiehl, J. T., Schwartz, S. E., and Benkovitz, C. M.: A description of the global sulfur cycle and its controlling processes in the National Center for Atmospheric Research Community Climate Model, J. Geophys. Res., 105, 13671385, 2000.

Rasch, P. J., Collins, W. D., and Eaton, B. E.: Understanding the Indian Ocean Experiment (INDOEX) aerosol distributions with an aerosol assimilation, J. Geophys. Res., 106(D7), 7337-7355, 2001.

Roesch, A.: Evaluation of surface albedo and snow cover in AR4 coupled climate models, J. Geophys. Res., 111, D15111, doi:10.1029/2005JD006473, 2006.

Russell, L. M.: Aerosol organic-mass-to-organic-carbon ratios, Environ. Sci. Technol., 37, 2982-2987, 2003.

Takeuchi, N., Kohshima, S., and Seko, K.: Structure, Formation, and Darkening Process of Albedo-Reducing Material (Cryoconite) on a Himalayan Glacier: A Granular Algal Mat Growing on the Glacier, Arctic, Antarctic, and Alpine Research, 33(2), 155-122, 2001.

Textor, C., Schulz, M., Guibert, S., Kinne, S., Balkanski, Y., Bauer, S., Berntsen, T., Berglen, T., Boucher, O., Chin, M., Dentener, F., Diehl, T., Easter, R., Feichter, H., Fillmore, D., Ghan, S., Ginoux, P., Gong, S., Grini, A., Hendricks, J., Horowitz, L., Huang, P., Isaksen, I., Iversen, I., Kloster, S., Koch, D., Kirkevåg, A., Kristjansson, J. E., Krol, M., Lauer, A., Lamarque, J. F., Liu, X., Montanaro, V., Myhre, G., Penner, J., Pitari, G., Reddy, S., Seland, Ø., Stier, P., Takemura, T., and Tie, X.: Analysis and quantification of the diversities of aerosol life cycles within AeroCom, Atmos. Chem. Phys., 6, 1777-1813, doi:10.5194/acp-61777-2006, 2006.

van der Werf, G. R., Randerson, J. T., Giglio, L., Collatz, G. J., Kasibhatla, P. S., and Arellano Jr., A. F.: Interannual variability in global biomass burning emissions from 1997 to 2004, Atmos. Chem. Phys., 6, 3423-3441, doi:10.5194/acp-6-3423-2006, 2006.

Wang, B., Bao, Q., Hoskins, B., Wu, G., and Liu, Y.:, Tibetan Plateau warming and precipitation changes in East Asia, Geophys. Res. Lett., 35, L14702, doi:10.1029/2008GL034330, 2008.

Warren, S. G. and Wiscombe, W. J.: A model for the spectral albedo of snow. II: Snow containing atmospheric aerosols, J. Atmos. Sci., 37, 2734-2745, 1980.

Warren, S. G. and Wiscombe, W. J.: Dirty snow after nuclear war, Nature, 313, 469-470, 1985.

Wu, G. X, and Zhang, Y. S.: Tibetan Plateau Forcing and the Timing of the Monsoon Onset over South Asia and the South China Sea, Mon. Weather Rev., 126, 913-927, 1998.
Wu, T.-W. and Qian, Z.: The relationship between the Tibetan winter snow and the Asian summer monsoon and rainfall: an observational investigation, J Climate, 16, 2038-2051, 2003.

$\mathrm{Xu}$, J. and Chan, J. C. L.: First transition of the Asian summer monsoon in 1998 and the effect of the Tibet-tropical Indian Ocean thermal contrast, Journal of the Meteorological Society of Japan, 79, 241-253, 2001.

Xu, B. Q., Yao, T. D., Liu, X. Q., and Wang, N. L.: Elemental and organic carbon measurements with a two-step heating-gas chromatography system in snow samples from the Tibetan Plateau, Ann. Glaciol., 43, 257-263, 2006.

Xu, B. Q., Cao, J., Hansen, J., Yao, T., Joswiak, D. R., Wang, N., Wu, G., Wang, M., Zhao, H., Yang, W., Liu, X., and He, J.: Black soot and the survival of Tibetan glaciers, P. Natl. Acad. Sci. USA, 106(52), 22114-22118, doi:10.1073/pnas.0910444106, 2009.

Yanai, M., Li, C., and Song, Z.: Seasonal heating of the Tibetan Plateau and its effects on the evolution of the Asian summer monsoon, Journal of the Meteorological Society of Japan, 70, 319-351, 1992.

Yasunari, T., Kitoh, A., and Tokioka, T.: Local and remote responses to excessive snow mass over Eurasia appearing in the northern spring and summer climate-a study with the MRI GCM, Journal of the Meteorological Society of Japan, 69, 473-487, 1991.

Yasunari, T. J., Bonasoni, P., Laj, P., Fujita, K., Vuillermoz, E., Marinoni, A., Cristofanelli, P., Duchi, R., Tartari, G., and Lau, K.-M.: Estimated impact of black carbon deposition during premonsoon season from Nepal Climate Observatory - Pyramid data and snow albedo changes over Himalayan glaciers, Atmos. Chem. Phys., 10, 6603-6615, doi:10.5194/acp-10-6603-2010, 2010.

Yeh, T.-C., Gao, Y. X., Tang, M. C., Luo, S. W., Shen, C. B., Gao, D. Y., Song, Z. S., Qian, Y. F., Yuan, F. M., Li, G. Q., Ding, Y. H., Chen, Z. T., Zhou, M. Y., Yang, K. J., and Wang, Q. Q.: Meteorology of Qinhai- Xizhang (Tibetan) Plateau, Science Press, Beijing, 300 pp., 1979 (in Chinese).

Zender, C., Bian, H., and Newman, D.: Mineral Dust Entrainment and Deposition (DEAD) Model: Description and 1990s Dust Climatology, J. Geophys. Res., 108(D14), 4416, doi:10.1029/2002JD002775, 2003.

Zhang, Y., Li, T., and Wang, B.: Decadal change of the spring snow depth over the Tibetan Plateau: the associated circulation and influence on the east Asian summer monsoon, J. Climate, 17, 2780-2793, 2004. 